\title{
Self-assembly of a helical zinc-europium complex: speciation in aqueous solution and luminescence
}

\author{
Emmanuel Deiters ${ }^{1}$, Svetlana V. Eliseeva ${ }^{1,2}$ and Jean-Claude G. Bünzli ${ }^{1,3 *}$ \\ 1 Institute of Chemical Sciences and Engineering, École Polytechnique Fédérale de Lausanne, Lausanne, Switzerland \\ ${ }^{2}$ Centre de Biophysique Moléculaire, Centre National de la Recherche Scientifique UPR 4301, Orléans, France \\ ${ }^{3}$ Department of Advanced Materials Chemistry, WCU Center for Next Generation Photovoltaic Systems, Korea University, Sejong-si, South Korea
}

Edited by:

Thorfinnur Gunnlaugsson, University of Dublin, Ireland

Reviewed by:

Thorfinnur Gunnlaugsson, University of Dublin, Ireland

Byeong-Soo Bae, Korea Advanced

Institute of Science and Technology, South Korea

Steve Comby, Trinity College Dublin, Ireland

\section{*Correspondence:}

Jean-Claude G. Bünzli, Institute of

Chemical Sciences and Engineering,

École Polytechnique Fédérale de

Lausanne, BCH 1402, Avenue

Forel 2, CH-1015 Lausanne,

Switzerland

e-mail: jean-claude.bunzli@epfl.ch
Two new tridentate(NNO)-bidentate(NN) compartmental ligands, $\mathrm{HL}^{5}$ and $\mathrm{HL}^{6}$, are synthesized from pyridine and benzimidazole synthons. They react in aqueous solution under physiological conditions with $\mathrm{Zn} \|$, $\mathrm{Ln}^{\mathrm{III}}$, or a mixture thereof, to yield complexes of different stoichiometries, 1:3, 2:2, 2:3, 1:1:3, the speciation of which is established by UV-visible titrations and ESI mass spectrometry. Photophysical studies of the Eull-containing solutions in Tris- $\mathrm{HCl} 0.1 \mathrm{M}(\mathrm{pH}=7.4)$ show that lanthanide luminescence arises from a unique $\mathrm{N}_{6} \mathrm{O}_{3}$ coordination site with pseudo $D_{3}$ symmetry. Relevant parameters such as crystal field splitting, lifetime, radiative lifetime, and intrinsic quantum yield perfectly match those reported for dinuclear $4 \mathrm{f}-4 \mathrm{f}$ helicates in which the Eu $\mathrm{u}^{\prime \prime \prime}$ ion has the same coordination environment.

Keywords: lanthanides, rare earths, self-assembly, dinuclear, bimetallic, stability constant, luminescence, helicates

\section{INTRODUCTION}

Helical structures have attracted chemists' attention when Linus Pauling published a seminal series of papers at the beginning of the 1950's dealing with the secondary structures of proteins induced by three-dimensional helical patterns (Pauling et al., 1951). The demonstration that helical structures can also be engineered at the molecular level by taking advantage of stereochemical properties of metal ions had to wait until 1987 when Jean-Marie Lehn isolated 3:2 $\mathrm{Cu}^{\mathrm{I}}: \mathrm{L}$ double-stranded helical complexes that he named helicates, where $\mathrm{L}$ is an oligo-bipyridine ligand (Lehn et al., 1987). A few years later, Claude Piguet applied the same concept to trivalent lanthanide ions and successfully self-assembled the first $\mathrm{Ln}^{\mathrm{III}}$ dinuclear triple-stranded helicate, $\left[\mathrm{Eu}_{2}\left(\mathrm{~L}^{\mathrm{A}}\right)_{3}\right]^{6+}$ (Scheme 1), the crystal structure of which evidences a stabilization of the molecular architecture by $\pi-\pi$ stacking interactions between the ligand strands (Bernardinelli et al., 1992). The two 9-coordinate metal ions lie on a pseudo- $C_{3}$ axis of symmetry (Figure 1); in solution the average symmetry of the edifice is $D_{3}$ on NMR time scale (Piguet et al., 1993). This initial work paved the way for the development of several series of lanthanide polynuclear and polymetallic complexes including heterobimetallic nd-4f (Piguet et al., 1995a) and 4f-4f' (André et al., 2004) chelates, as well as tri- and tetranuclear homometallic and heterometallic entities (Piguet et al., 2000; Piguet and Bünzli, 2010). Interestingly, the helicates are quite stable in solution despite large Coulomb repulsion between two neighboring cations which lie about $9 \AA$ apart; careful thermodynamic considerations for $3 \mathrm{~d}-4 \mathrm{f}$ and $4 \mathrm{f}-4 \mathrm{f}-4 \mathrm{f}$ helicates indeed show that the cation-cation repulsive energy $\left(\approx 700 \mathrm{~kJ} \cdot \mathrm{mol}^{-1}\right)$ is largely compensated by favorable solvation energy (Canard and Piguet,
2007). Furthermore, soluble helicates $\left[\mathrm{Ln}_{2}\left(\mathrm{~L}^{\mathrm{Cl}}\right)_{3}\right]$ can be assembled in water and are highly stable, with $\log \beta_{23}$ on the order of 26-30 (Elhabiri et al., 1998). Crystal structures revealed triplestranded helicates with 9-coordinate metal ions $(\mathrm{Ln}=\mathrm{Eu}, \mathrm{Tb})$ well-imbedded into the edifice and displaying interesting photophysical properties (Elhabiri et al., 1998; Gonçalves e Silva et al., 2002). Subsequent molecular engineering led to the series of the more water-soluble $\left[\mathrm{Ln}_{2}\left(\mathrm{~L}^{\mathrm{C} 2}\right)_{3}\right]$ helicates and their bioconjugates which proved to be adequate luminescent bioprobes for live cell staining (Song et al., 2008; Chauvin et al., 2013) and for specific detection of biomarkers expressed by cancerous cells (Fernandez-Moreira et al., 2010).

One fascinating aspect of the polymetallic helical molecular edifices is the possibility of controlling the optical and/or magnetic properties of one ion by the other, through communication along the pseudo $C_{3}$ axis. Examples are the tuning of the spincrossover temperature in $\left[\mathrm{FeLn}\left(\mathrm{L}^{1,2}\right)_{3}\right]^{5+}$ (Piguet et al., 1995b; Edder et al., 2000, 2001), (Scheme 1) or the lengthening of the excited state lifetimes of $\mathrm{Nd}^{\mathrm{III}}$ and $\mathrm{Yb} \mathrm{bII}^{\mathrm{III}}$ in $\left[\mathrm{CrLn}\left(\mathrm{L}^{1}\right)_{3}\right]^{6+}$ (Torelli et al., 2005). Such tunability would be of great help in the design of specific biosensors and stains, especially that $\left[\operatorname{EuZn}\left(\mathrm{L}^{2}\right)_{3}\right]^{5+}$ proved to be quite luminescent in water with a quantum yield of 15\% (Edder et al., 1997; Piguet and Bünzli, 2010). Bioprobes need to be water soluble and amenable to bioconjugation; unfortunately, helicates with the carboxylic acid derivatives $\mathrm{HL}^{3}$ and $\mathrm{HL}^{4}$ do not show enough water solubility for this purpose. In this paper, we apply to $\mathrm{HL}^{3}$ the successful strategy used in going from $\mathrm{H}_{2} \mathrm{~L}^{\mathrm{C1}}$ to $\mathrm{H}_{2} \mathrm{~L}^{\mathrm{C} 2}$ in the hope of gaining access to luminescent and soluble $3 \mathrm{~d}-4 \mathrm{f}$ helicates with ligands $\mathrm{HL}^{5}$ and $\mathrm{HL}^{6}$. More specifically, and as a first step toward engineering bioprobes based 

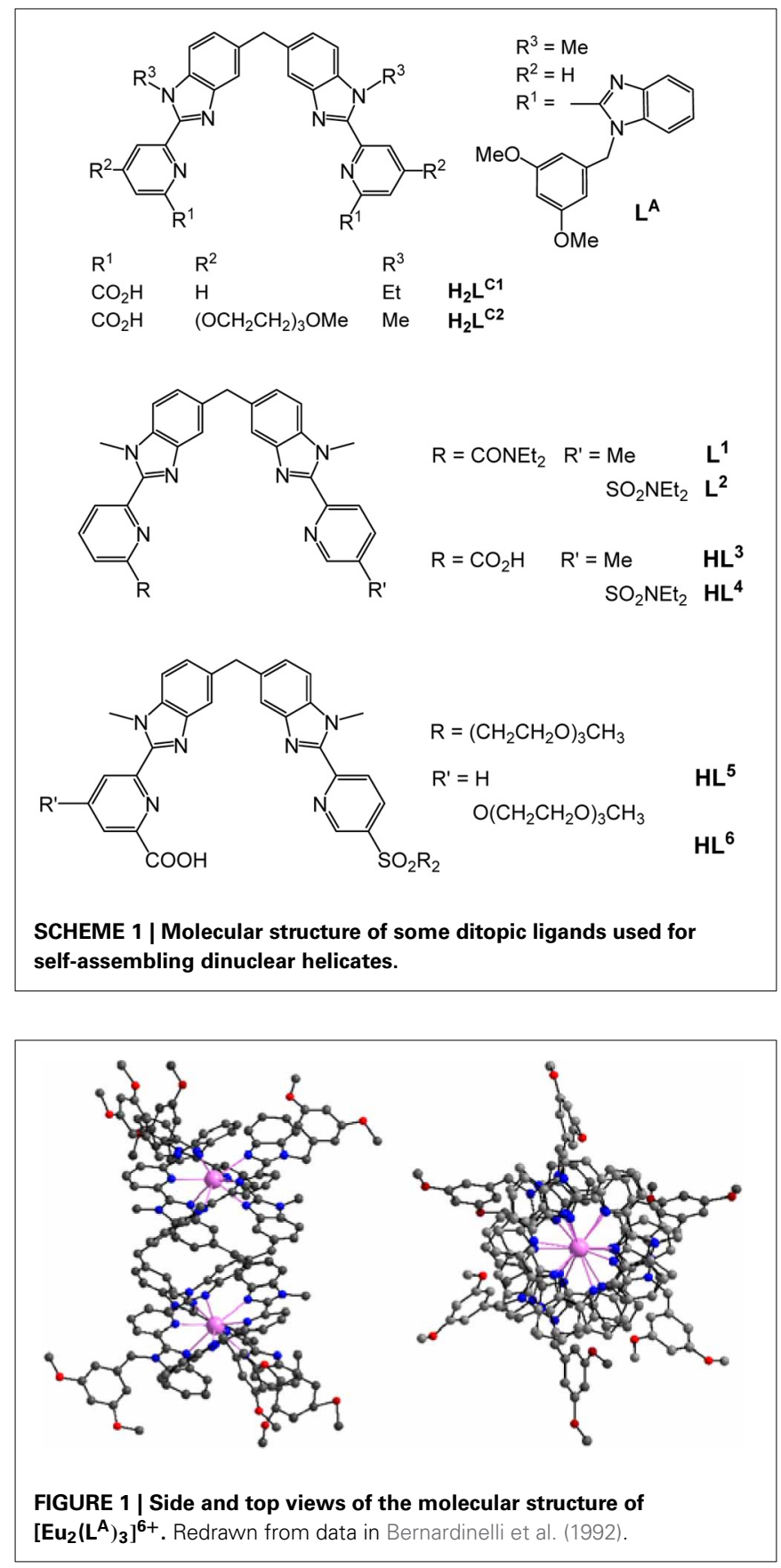

on such compounds, complex formation in the $\mathrm{Eu}^{\mathrm{III}}-\mathrm{Zn}^{\mathrm{II}}-\mathrm{HL}^{6}$ system and associated luminescent properties are investigated. Spectroscopically silent $\mathrm{Zn}^{\mathrm{II}}$ has been chosen because it allows studying the coordination environment of the $\mathrm{Eu}^{\mathrm{III}}$ ion without interference from the $\mathrm{M}^{\mathrm{II}}$ ion.

\section{RESULTS AND DISCUSSION \\ LIGAND SYNTHESIS}

The underlying principle of the synthesis of $\mathrm{HL}^{5}$ and $\mathrm{HL}^{6}$ is the same as the one adopted for preparing ligands $\mathrm{L}^{1,2}$ (Edder et al., 2000), and $\mathrm{HL}^{3}$ (Edder et al., 1997), namely a multistep strategy based on a modified Phillips reaction for the formation of the benzimidazole rings. However, the diethylamino groups are replaced by 2-[2-(2-methoxyethoxy)ethoxy]- $\mathrm{N}-\{2-[2-$ (2-methoxyethoxy)ethoxy] ethyl\}-ethanamino groups. Following our previous work (Deiters et al., 2009), the latter have been grafted on the key intermediate (6), the synthesis of which is depicted on Scheme 2 while the routes for accessing ligands $\mathrm{HL}^{5}$ and $\mathrm{HL}^{6}$ are summarized on Scheme 3. Regarding sulfonation, the absence of directional electronic effects favoring electrophilic substitution in the ditopic ligands and the large number of carbon atoms amenable to sulfonation implies that the corresponding group has to be inserted in one of the starting building blocks, namely (3).

Intermediate (6) was prepared in 7 steps and $23 \%$ yield from commercially available 2-picoline, benzylamine and triethylene glycol monomethyl ether (TEGOMe). The first two steps involve the synthesis of 2-[2-(2-methoxyethoxy)ethoxy]$\mathrm{N}$-\{2-[2-(2-methoxyethoxy)-ethoxy]ethyl\}ethanamine (2): two TEGOMe arms are grafted on the primary benzylamine by reaction with BrTEGOMe in presence of a weak base (reaction i, Scheme 2) followed by selective and quantitative cleavage of the benzylamino group by continuous flow hydrogenation (reaction ii). Two other steps are necessary for preparing (3) from 2-picoline by treatment with oleum and subsequent oxidation with permanganate, according to a previously described procedure (Delarge, 1965). The sulfonate function of (3) is then activated by chlorination (reaction iii), in presence of a $\mathrm{PCl}_{5} / \mathrm{POCl}_{3}$ mixture to give the corresponding sulfonyl chloride (4). Coupling between (2) and (4) is subsequently achieved under standard conditions (reaction iv) to yield sulfonamide (5). Finally, oxidation of the methyl group of (5) into a carboxy group conducted in presence of an excess of $\mathrm{SeO}_{2}$ in refluxing pyridine affords synthon (6) in almost quantitative yield (reaction v).

Preparation of the segmental ligands $\mathrm{HL}^{5,6}$ is divided in fourth steps. Firstly, sequential Phillips coupling reactions (reactions vi/vii, Scheme 3) with successive introduction of different pyridine arms, (6), (7), and (9), are performed on the central dinitro, bis-( $N$-methylamino)diphenylmethane synthon (8). Secondly, the resulting bis-amides (11) and (14) are reduced (reactions viii, ix) in presence of a large excess of iron to form the bis(benzimidazole) intermediates (12) and (15). Finally, basic hydrolysis of both ethylester functions (reactions $\mathrm{x}$ ) leads to the targeted segmental ligands with overall yields (steps iii-x in Schemes 2, 3) of 18.8 and $18.4 \%$ for $\mathrm{HL}^{5}$ and $\mathrm{HL}^{6}$, respectively.

\section{SPECIATION IN SOLUTION}

Conditional stability constants of both homometallic $\left(\mathrm{M}=\mathrm{Zn}^{\mathrm{II}}\right.$, $\left.\mathrm{La}^{\mathrm{III}}, \mathrm{Eu}^{\mathrm{III}}, \mathrm{Lu}^{\mathrm{III}}\right)$ and heterometallic $\left(\mathrm{M}^{1}=\mathrm{Zn}^{\mathrm{II}}, \mathrm{M}^{2}=\mathrm{La}^{\mathrm{III}}\right.$, $\left.\mathrm{Eu}^{\mathrm{III}}, \mathrm{Lu}^{\mathrm{III}}\right)$ complexes have been determined in Tris- $\mathrm{HCl} 0.1 \mathrm{M}$ ( $\mathrm{pH} 7.4)$ at $295 \mathrm{~K}$ by spectrophotometric titrations of the ligands $\left(1.43 \times 10^{-5} \mathrm{M}\right.$ for $\mathrm{HL}^{5}$ and $1.62 \times 10^{-5} \mathrm{M}$ for $\mathrm{HL}^{6}$, corresponding to an absorbance of about 0.5 ) with concentrated solutions of the metal perchlorates: $2.5-5.0 \times 10^{-3} \mathrm{M}$ for homometallic titrations and $2 \times 10^{-4} \mathrm{M}$ for each cation in the case of heterometallic titrations, in view of the poorer solubility of the hetero species. Titrations were performed batch wise for $20-25[\mathrm{M}]_{t} /\left[\mathrm{HL}^{i}\right]_{t}(i=5.6)$ ratios ranging between 0 and 2 


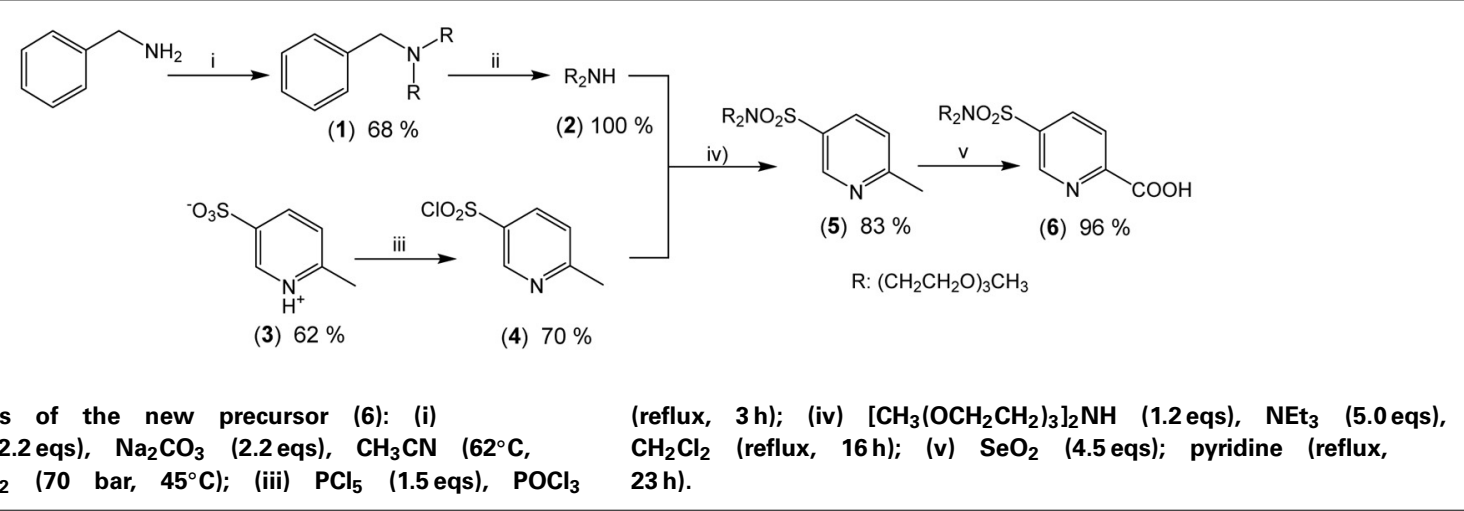

SCHEME 2 | Synthesis of the new precursor (6): (i)
$\mathrm{CH}_{3}\left(\mathrm{OCH}_{2} \mathrm{CH}_{2}\right)_{3} \mathrm{Br}(2.2 \mathrm{eqs}), \mathrm{Na}_{2} \mathrm{CO}_{3}(2.2 \mathrm{eqs}), \mathrm{CH}_{3} \mathrm{CN}\left(62^{\circ} \mathrm{C}, \mathrm{CH}_{2} \mathrm{Cl}_{2}\right.$
$76 \mathrm{~h}) ;\left(\right.$ ii) $\mathrm{Pd} / \mathrm{C}, \mathrm{H}_{2}\left(70\right.$ bar, $\left.45^{\circ} \mathrm{C}\right)$; (iii) $\left.\mathrm{PCl}_{5}(1.5 \mathrm{eqs}), \mathrm{POCl}_{3} 23 \mathrm{~h}\right)$.

$76 \mathrm{~h})$; (ii) $\mathrm{Pd} / \mathrm{C}, \mathrm{H}_{2}\left(70\right.$ bar, $\left.45^{\circ} \mathrm{C}\right)$; (iii) $\mathrm{PCl}_{5}$ (1.5 eqs), $\mathrm{POCl}_{3} 23 \mathrm{~h}$ ).

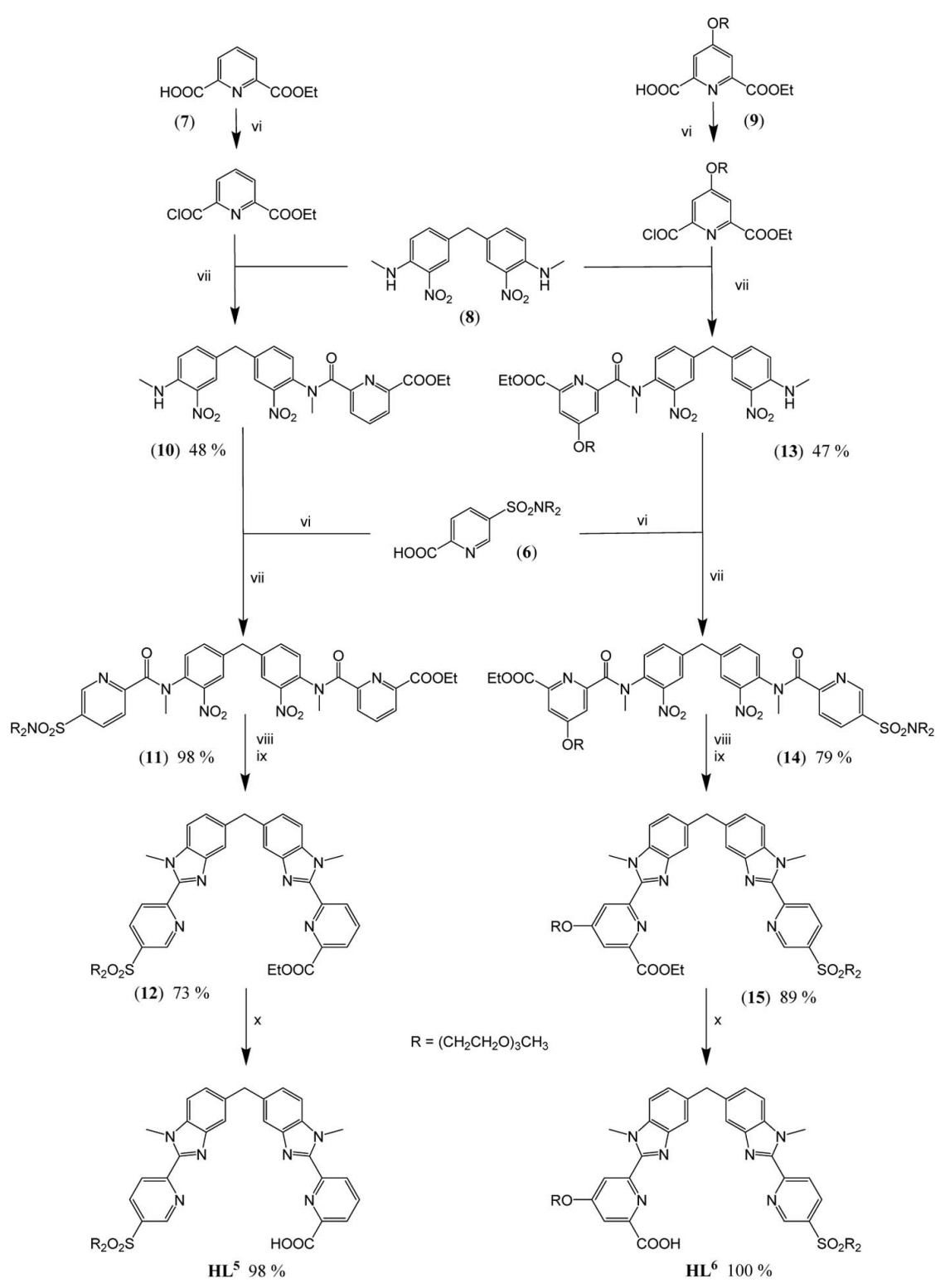

SCHEME 3 | Synthesis of $\mathrm{HL}^{5}$ and $\mathrm{HL}^{6}$ : (vi) (6), (7), or (9) (1.0 eq.), $\mathrm{SOCl}_{2}$ (10 eqs), DMF (0.5 eq.), $\mathrm{CH}_{2} \mathrm{Cl}_{2}$ (reflux, $2 \mathrm{~h}$ ); (vii) (8) (0.9 eq.), (10) (0.6 eq.) or (13) (0.4 eq.), $\mathrm{NEt}_{3}, \mathrm{CH}_{2} \mathrm{Cl}_{2}$ (reflux, $16 \mathrm{~h}$ ); (viii) (11) or (14)
(1.0 eq.), $\mathrm{Fe}\left(30 \mathrm{eqs}\right.$ ), EtOH $/ \mathrm{H}_{2} \mathrm{O} / \mathrm{HCl}$ (reflux, $16 \mathrm{~h}$ ); (ix) $\mathrm{EtOH} / \mathrm{H}_{2} \mathrm{SO}_{4}$ (reflux, $4 \mathrm{~h}$ ); (x) (12) or (15) (1.0 eq.), $\mathrm{NaOH}$ (1.2 eqs), $\mathrm{EtOH} / \mathrm{H}_{2} \mathrm{O}$ $\left(60^{\circ} \mathrm{C}, 16 \mathrm{~h}\right)$. 
( 0 and 4 for $\mathrm{Eu}^{\mathrm{III}}+\mathrm{Zn}^{\mathrm{II}}$, respectively). The first attempts to determine the speciation of the complexes revealed unreliable due to the slow kinetic of formation. Therefore, the time required to reach equilibrium was determined by luminescence spectroscopy, monitoring both the ligand fluorescence $\left(\mathrm{Zn}^{\mathrm{II}}-\mathrm{HL}^{6}\right.$ and $\mathrm{Gd}^{\mathrm{III}}-$ $\mathrm{HL}^{6}$ systems) and the phosphorescence of the $\mathrm{Eu}^{\mathrm{III}}$ ion $\left(\mathrm{Eu}^{\mathrm{III}}-\mathrm{HL}^{6}\right.$ and $\mathrm{Eu}^{\mathrm{III}}-\mathrm{Zn}^{\mathrm{II}}-\mathrm{HL}^{6}$ systems). In the case of the lanthanide solutions with 1:3 and 2:3 Ln:HL ${ }^{6}$ ratios, steady states were reached within times not exceeding $1 \mathrm{~h}$ at room temperature. On the other hand, equilibrium times could be estimated at about 5-6 days at $313 \mathrm{~K}$ for heterometallic solutions. Consequently, solutions were carefully equilibrated before recording spectra, taking these data into consideration: $2 \mathrm{~h}$ at room temperature for homometallic solutions and 7 days at $313 \mathrm{~K}$ for heterometallic mixtures. These observations are interesting because in previous works, the kinetics of formation of homodinuclear $4 \mathrm{f}-4 \mathrm{f}$ helicates with a ligand similar to $\mathrm{HL}^{\mathrm{C} 1}$ but with carboxylic acid groups replaced with diethylamide groups (Hamacek et al., 2003) or with a bis (8-hydroxyquinolinate) ligand (Comby et al., 2009) was found to be fast in acetonitrile, equilibrium being reached within minutes. Similarly, $\left[\mathrm{Eu}_{2}\left(\mathrm{~L}^{\mathrm{Cl}}\right)_{3}\right]$ forms within $10 \mathrm{~min}$ in water at pH 6.15 (Elhabiri et al., 2004). If the observed kinetics for the 1:3 and 2:3 Ln:HL ${ }^{6}$ complexes is not too different from the latter observation, formation of the $\mathrm{Zn}^{\mathrm{II}} \mathrm{Eu}^{\mathrm{III}}$ helicate is about two orders of magnitude slower.

In the case of ligand $\mathrm{HL}^{5}$, the spectra corresponding to the titration with lanthanum could be analyzed with a model including $\left[\mathrm{La}\left(\mathrm{L}^{5}\right)_{n}\right]^{(3-n)+}(n=1,2,3)$ and $\left[\mathrm{La}_{2}\left(\mathrm{~L}^{5}\right)_{3}\right]^{3+}$ species: the corresponding $\log \beta_{1 n}$ and $\log \beta_{23}$ being 8.4(3), 14.2(5), 20.4(4), and 29.2(6), pointing to the formation of a very stable helicate, despite the mismatch between the ligand denticity $(3+2)$ and the coordination number requirements of $\mathrm{La}^{\mathrm{III}}$. On the other hand, data with lutetium gave a less satisfying fit. Moreover, when the ligand was titrated with zinc ions or with an equimolar mixture of zinc and lanthanide ions partial precipitation occurred and the residual absorbance at the end of the titration was markedly smaller than at the beginning. For this reason, no further experiments have been conducted with $\mathrm{HL}^{5}$ and we have concentrated our efforts on ligand $\mathrm{HL}^{6}$.

For the titrations of $\mathrm{HL}^{6}$ with $\mathrm{Zn}^{\mathrm{II}}$ and $\mathrm{Eu}^{\mathrm{III}}$, factor analysis pointed to the presence of 3-4 species in solution, including the free ligand. However, the fitting procedure was not straightforward and several models were tested. The best convergence and smallest residuals were obtained for the following sets of equilibria (charges are omitted for clarity):

$$
\begin{array}{ll}
\mathrm{Zn}+3 \mathrm{~L}^{6} \leftrightarrows\left[\mathrm{Zn}\left(\mathrm{L}^{6}\right)_{3}\right] & \log \beta_{13} \\
2 \mathrm{Zn}+2 \mathrm{~L}^{6}+\leftrightarrows\left[\mathrm{Zn}_{2}\left(\mathrm{~L}^{6}\right)_{2}\right] & \log \beta_{22} \\
2 \mathrm{Zn}+3 \mathrm{~L}^{6}+\leftrightarrows\left[\mathrm{Zn}_{2}\left(\mathrm{~L}^{6}\right)_{3}\right] & \log \beta_{23} \\
\mathrm{Eu}+3 \mathrm{~L}^{6} \leftrightarrows\left[\mathrm{Eu}\left(\mathrm{L}^{6}\right)_{3}\right] & \log \beta_{13} \\
2 \mathrm{Eu}+3 \mathrm{~L}^{6} \leftrightarrows\left[\mathrm{Eu}_{2}\left(\mathrm{~L}^{6}\right)_{3}\right] & \log \beta_{23}
\end{array}
$$

Recalculated spectra are heavily correlated (Figures S1, S2, Supplementary Material), which explains the difficulties in the fitting procedure. The corresponding conditional stability constants are listed in Table 1. In the case of $\mathrm{Zn}^{\mathrm{II}}$, the main species at 2:3 Zn:L stoichiometric ratio is the dinuclear complex (Figure 2, top) while the 1:3 complex remains a minor species (maximum speciation: $21 \%$ at $R=0.20$ ); when $R$ further increases, the $2: 3$ complex transforms into a $2: 2$ species. This behavior is in line with our previous results (Piguet and Bünzli, 2010). The tridentate-bidentate compartmental ligand $\mathrm{HL}^{6}$ is not well-suited for building triple-stranded helicates with $\mathrm{Ln}^{\mathrm{III}}$ ions (two tridentate coordination units would be required) and this is seen in the corresponding speciation diagram: the dominant species is a 1:3 complex, with a 75\% speciation for $R=0.33$ (Figure 2, middle). For this ratio, only a small quantity of the $2: 3$ species is present $(8 \%)$. Absorbance values extracted at different wavelengths for the titrations with $\mathrm{Zn}^{\mathrm{II}}$ and $\mathrm{Eu}^{\mathrm{III}}$ (Figures S1, S2, Supplementary Material) are compatible with the initial formation of 1:3 species.

The titration with a mixture of metal ions has been conducted in a slightly different way, due to reduced solubility of the formed products, the concentration of each metal ion has been set to $2.00 \times 10^{-4} \mathrm{M}$ only. Again fit of the data was difficult in view of the correlated spectra (Figure S3, Supplementary Material), so that the extracted data and corresponding discussion have to be taken with care. Indeed, $\log \beta_{22}$ for $\left[\mathrm{Zn}_{2}\left(\mathrm{~L}^{6}\right)_{2}\right]^{2+}$ extracted from this titration amounts to 18.7(3) whereas a value of 21.7(4) was found from the homometallic titration. We think, however, that the salient features are correct: contrary to what was expected, and found for other $\mathrm{Zn}^{\mathrm{II}}-\mathrm{Ln}^{\mathrm{III}}$ helicates in acetonitrile, for instance with $\mathrm{L}^{2}$ (Edder et al., 2000), the 1:1:3 species is not the dominant one, accounting for only $38 \%$ of the speciation at the 1:1:3 stoichiometric ratio. Another species is present in sizeable quantity (18\%), namely the $\mathrm{Zn}^{\mathrm{II}} 2: 2$ complex which is less stable than the 1:1:3 species by less than two orders of magnitude. So it seems there is competition between $\mathrm{Zn}^{\mathrm{II}}$ and $\mathrm{Eu}^{\mathrm{III}}$ for the tridentate coordination unit of $\left(\mathrm{L}^{6}\right)^{-}$. This competition is further demonstrated by an experiment in which $\mathrm{Zn}^{\mathrm{II}}$ was added to a $1: 3 \mathrm{Eu}:\left(\mathrm{L}^{6}\right)^{-}$stoichiometric solution $5.4 \mu \mathrm{M}$ in $\mathrm{Eu}^{\mathrm{III}}$ up to an Eu:Zn ratio equal to 1 . The Eu ${ }^{I I I}$ luminescence intensity clearly decreases while ligand fluorescence centered at $450 \mathrm{~nm}$ increases (Figures S4, S5, Supplementary Material). Moreover, the ES-MS spectra discussed below point to other species being present in solution and the low solubility exhibited by this mixed system could well reflect the formation of polymeric (hydroxide?) species as well.

In order to substantiate the speciation determined by UVvisible titrations and, also, to determine if lighter and heavier lanthanides would lead to the same species in solution, ES-MS

Table 1 | Conditional stability constants in Tris- $\mathrm{HCl}(0.1 \mathrm{M}, \mathrm{pH} 7.4)$ and $295 \mathrm{~K}$ extracted from the spectrophotometric titrations of $\mathrm{HL}^{6}$.

\begin{tabular}{lllll}
\hline Metal ion(s) & $\log \beta_{\mathbf{1 3}}$ & $\log \beta_{\mathbf{2 2}}$ & $\log \beta_{\mathbf{2 3}}$ & $\log \beta_{\mathbf{1 1 3}}$ \\
\hline$Z n^{\prime \prime}$ & $18.3(4)$ & $21.7(4)$ & $27.8(4)$ & - \\
$E u^{\prime \prime \prime}$ & $17.5(2)$ & - & $22.8(2)$ & - \\
$Z n^{\prime \prime}+E u^{\prime \prime \prime}(1: 1)$ & - & $18.7(3)$ & - & $20.6(3)$ \\
\hline
\end{tabular}

Standard deviations are given within parentheses. 

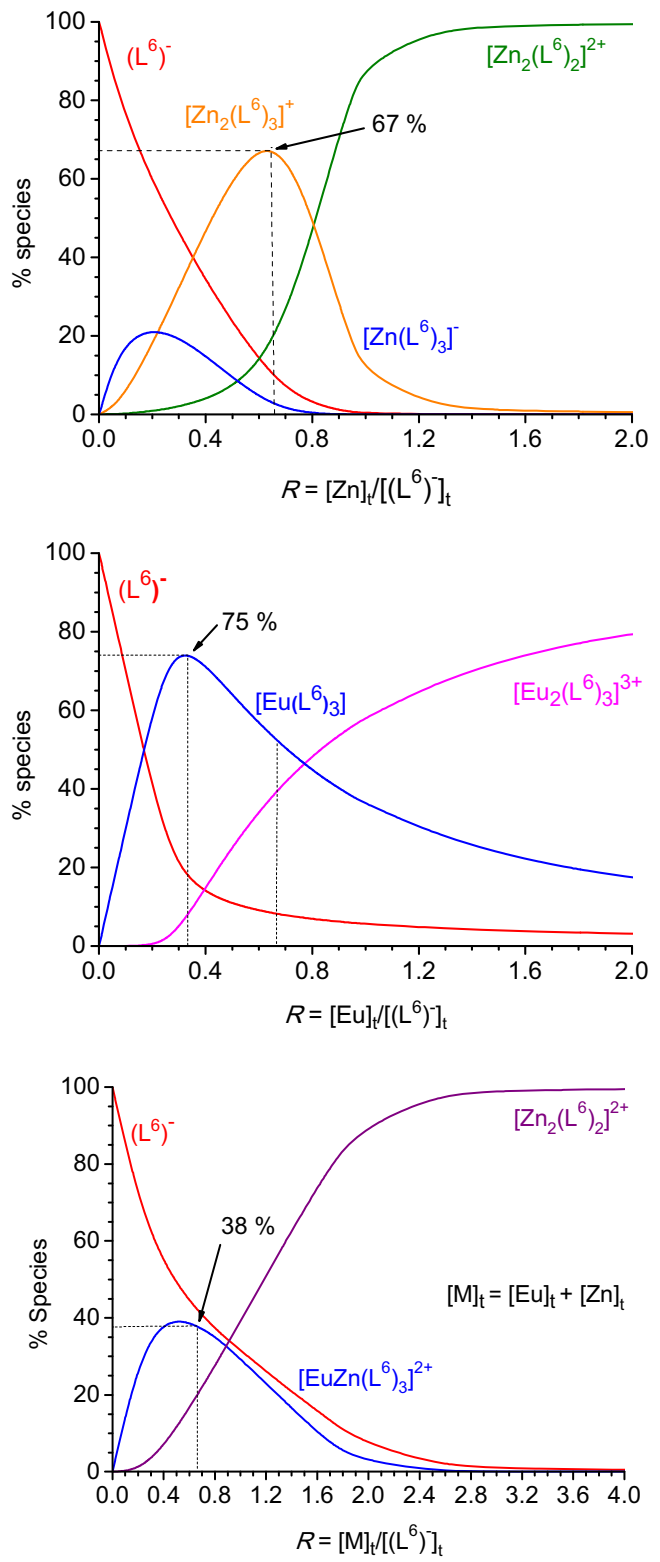

FIGURE 2 | Speciation diagrams calculated from the titration of $\mathrm{HL}^{6}$ $1.62 \times 10^{-5} \mathrm{M}$ in Tris-HCl (pH 7.4) at $295 \mathrm{~K}$ with zinc (top), europium (middle), and zinc + europium (1:1, bottom) perchlorates.

Corresponding stability constants are listed in Table $\mathbf{1}$.

spectra of 1:1:3 Zn:Ln:( $\left(\mathrm{L}^{6}\right)^{-}$solutions in acetonitrile:water (1:1) containing $1 \%$ of formic acid and with total ligand concentration equal to $3 \mathrm{mM}$ have been recorded for $\mathrm{Ln}=\mathrm{Nd}$ and $\mathrm{Yb}$. The main observed peaks are listed in Table 2. The findings indeed partly corroborate those from UV-visible titrations. For the Nd-containing sample, the $\left[\mathrm{ZnNd}\left(\mathrm{L}^{6}\right)_{3}\right]^{2+}$ complex is detected as a quadruple charged $\left(+2 \mathrm{H}^{+}\right)$species, along with $\left[\mathrm{Nd}\left(\mathrm{L}^{6}\right)_{3}\right]$ and $\left[\mathrm{Zn}\left(\mathrm{L}^{6}\right)_{2}\right]$, the latter giving rise to several solvated species and/or adducts with sodium and potassium. Spectra for the $\mathrm{Yb}$-containing samples are simpler; here again, the 1:1:3 species is detected through a peak with a sizeable intensity the high-resolution scan of which matches well the calculated isotopic distribution (Figure 3). As for neodymium, an ytterbium $1: 3$ species is present, as well as the 1:2 zinc complex. In both cases, no 2:2 zinc complex was identified though, contrary to UV-visible titration data; we note, however that the solvent is different and that the conditions in the spectrometer may lead to dissociation of this species.

\section{PHOTOPHYSICAL PROPERTIES OF THE SOLUTIONS}

Absorption spectra of ligand $\left(\mathrm{L}^{6}\right)^{-}$and various solutions containing $\mathrm{Ln}^{\mathrm{III}}$ ions $(\mathrm{Ln}=\mathrm{Eu}, \mathrm{Gd})$ or an equimolar $\mathrm{Eu}^{\mathrm{III}} / \mathrm{Zn}^{\mathrm{II}}$ mixture are reported on Figure 4. The ligand absorption band at $319 \mathrm{~nm}$ can be assigned to a $\pi \rightarrow \pi^{*}$ transition involving intramolecular electron transfer from the benzimidazole units to the pyridine and carboxylic groups. This band is red-shifted to $326.5-327 \mathrm{~nm}$ in the solutions containing $\mathrm{Ln}^{\mathrm{III}}$ ions only while the presence of $\mathrm{Zn}^{\mathrm{II}}$ results in a slightly larger shift, to $329.5 \mathrm{~nm}$. The molar absorption coefficients of the 1:3 solutions are, within experimental errors, equal to three times the molar absorption coefficient of the free ligand, while they are marginally smaller $(-3.5 \%)$ for the 2:3 and 1:1:3 solutions (Table 3 ).

Upon excitation into the 319-nm absorption band, ligand fluorescence emission is seen as a broad feature with maximum at $466 \mathrm{~nm}$ (Figure 5) and the corresponding excitation spectrum matches the absorption spectrum. At $77 \mathrm{~K}$ and upon enforcing a $50-\mu$ s delay time, weak phosphorescence is detected with a maximum at $506 \mathrm{~nm}$. For the 1:3 $\mathrm{Eu}^{\mathrm{III}}$ solution, fluorescence of the ligand is still seen, representing $37 \%$ of the total emission of the sample; this is consistent with the fact that the solution contains about $17 \%$ of free ligand (Figure 2, middle). In addition characteristic $\mathrm{f}$-f emission from the $\mathrm{Eu}\left({ }^{5} \mathrm{D}_{0}\right)$ level is detected. A striking feature is that this spectrum is quite typical of a species with pseudo $D_{3}$ symmetry and is quasi identical to the one recorded for the $\left[\mathrm{Eu}_{2}\left(\mathrm{~L}^{\mathrm{C} 2}\right)_{3}\right]$ helicate (Chauvin et al., 2008). In particular, the branching ratios expressed with respect to the intensity of the magnetic dipole transition, $I\left({ }^{5} \mathrm{D}_{0} \rightarrow{ }^{7} \mathrm{~F}_{J}\right) / I\left({ }^{5} \mathrm{D}_{0} \rightarrow{ }^{7} \mathrm{~F}_{1}\right)$ are very similar for the two samples (data for $\left[\mathrm{Eu}_{2}\left(\mathrm{~L}^{\mathrm{C} 2}\right)_{3}\right]$ are between parentheses): 0.02 (0.01), 1.00 (1.00), 0.87 (0.95), 0.16 (0.13), 1.62 (1.72), and 0.05 (n.a.). The splitting of the ${ }^{5} \mathrm{D}_{0} \rightarrow{ }^{7} \mathrm{~F}_{1}$ transition is also very similar, 170 vs. $161 \mathrm{~cm}^{-1}$. These data point to luminescence arising from a coordination environment made up of $3 \mathrm{NNO}$ moieties and very similar to the sites in $\left[\mathrm{Eu}_{2}\left(\mathrm{~L}^{\mathrm{C} 2}\right)_{3}\right]$; if some coordination were to occur through the bidentate site, then the coordination sphere would be completed by water molecules, leading to a poorly luminescent species. The solution also contains $8 \%$ of the $2: 3$ species, featuring two different metal ion sites $(\mathrm{NNO})_{3}$ and $(\mathrm{NN})_{3}$; the first one will give a spectrum identical to the one of the 1:3 complex, while the second will be poorly luminescent and therefore its contribution to the emission spectrum can be neglected. As an additional proof, the decay curve of the $\mathrm{Eu}\left({ }^{5} \mathrm{D}_{0}\right)$ luminescence is perfectly monoexponential, with a lifetime of $2.7 \mathrm{~ms}\left(2.4 \mathrm{~ms}\right.$ for $\left.\left[\mathrm{Eu}_{2}\left(\mathrm{~L}^{\mathrm{C} 2}\right)_{3}\right]\right)$, confirming that emission essentially originates from very similar coordination environments. Emission spectra of solutions with stoichiometric ratios $\mathrm{Eu}:\left(\mathrm{L}^{6}\right)^{-} 2: 3$ and $\mathrm{Zn}: \mathrm{Eu}:\left(\mathrm{L}^{6}\right)^{-}$1:1:3 display spectra identical to the one of the 1:3 solution (Figure S6, Supplementary Material), consistent with the speciation reported in Figure 2; in particular, 
Table 2 | Main peaks observed in the ESI-MS spectra of heterometallic solutions containing $\mathrm{Zn}^{\mathrm{II}}, \mathrm{Nd}^{\mathrm{III}}$ or $\mathrm{Yb}^{\mathrm{III}}$, and $\left(\mathrm{L}^{6}\right)$ in stoichiometric ratio 1:1:3 in acetonitrile/ $\mathrm{H}_{2} \mathrm{O} /$ formic acid 49.5/49.5/1.

\begin{tabular}{|c|c|c|c|c|c|}
\hline Solution & Species & $m / z$ (exp.) & Int. & Assignment & $m / z$ (calcd) \\
\hline \multirow[t]{6}{*}{$1: 1: 3$} & {$\left[\mathrm{Nd}\left(\mathrm{L}^{6}\right)_{3}\right]$} & 1594.58 & 6 & {$[\mathrm{M}+\mathrm{Na}+\mathrm{H}]^{2+} / 2$} & 1594.59 \\
\hline & {$\left[\mathrm{Zn}\left(\mathrm{L}^{6}\right)_{2}\right]$} & 1040.39 & 50 & {$[\mathrm{M}+2 \mathrm{H}]^{2+} / 2$} & 1040.40 \\
\hline & & 1051.38 & 100 & {$[\mathrm{M}+\mathrm{Na}+\mathrm{H}]^{2+} / 2$} & 1051.39 \\
\hline & & 1062.37 & 65 & {$\left[\mathrm{M}+\mathrm{CH}_{3} \mathrm{CN}+2 \mathrm{H}\right]^{2+} / 2$} & 1062.40 \\
\hline & & 708.58 & 85 & {$[\mathrm{M}+2 \mathrm{Na}+\mathrm{H}]^{3+} / 3$} & 708.59 \\
\hline & & 713.90 & 85 & {$[\mathrm{M}+\mathrm{Na}+\mathrm{K}+\mathrm{H}]^{3+} / 3$} & 713.92 \\
\hline $\mathrm{Zn}: Y b:\left(\mathrm{L}^{6}\right)^{-}$ & {$\left[\mathrm{YbZn}\left(\mathrm{L}^{6}\right)_{3}\right]$} & 1087.73 & 25 & {$[\mathrm{M}+\mathrm{H}]^{3+} / 3$} & 1087.38 \\
\hline \multirow[t]{2}{*}{$1: 1: 3$} & {$\left[\mathrm{Yb}\left(\mathrm{L}^{6}\right)_{3}\right]$} & 1620.10 & 5 & {$[\mathrm{M}+2 \mathrm{Na}]^{2+} / 2$} & 1620.10 \\
\hline & {$\left[\mathrm{Zn}\left(\mathrm{L}^{6}\right)_{2}\right]$} & 1062.38 & 35 & {$[\mathrm{M}+2 \mathrm{Na}]^{2+} / 2$} & 1062.38 \\
\hline
\end{tabular}

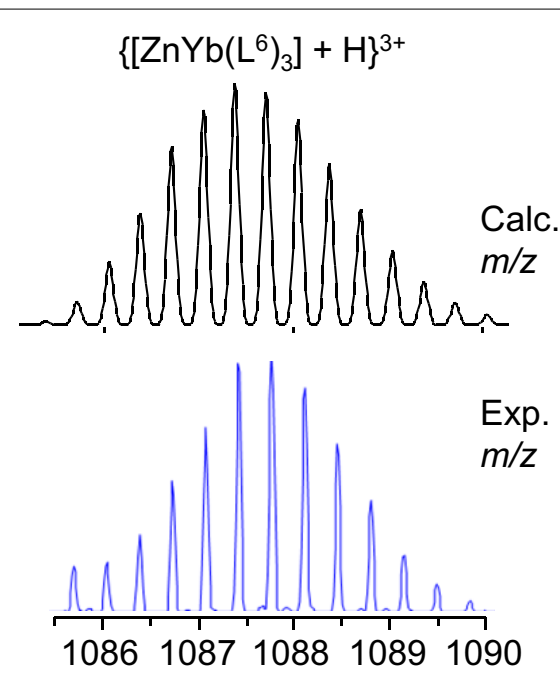

FIGURE 3 | Calculated (top) and experimental (bottom) isotopic distribution for $\left\{\left[\mathrm{ZnYb}\left(\mathrm{L}^{6}\right)_{3}\right]+\mathrm{H}\right\}^{3+}$.

the emission intensity of the heterometallic solution is weak, due to the low concentration in $1: 1: 3$ species $(38 \%$, which translates in $19 \%$ with respect to the europium site).

Low-temperature emission spectra are presented on Figure 6 for the ligand, a $\mathrm{Gd}^{\mathrm{III}}$-containing solution and the Eu: $\mathrm{Zn}$ 1:1 sample. Upon enforcing a 50- $\mu$ s delay time, fluorescence of the ligand almost disappears to the benefit of a phosphorescence band centered at $509 \mathrm{~nm}$. In the $\mathrm{Gd}:\left(\mathrm{L}^{6}\right)^{-} 1: 3$ sample, this band is red shifted at $525 \mathrm{~nm}$ and presents a vibrational structure (463, $494,525,559 \mathrm{~nm}$ ) with $\approx 1200 \mathrm{~cm}^{-1}$ spacing, typical of a ring breathing mode. The Eu:Zn sample also displays ligand fluorescence and phosphorescence, again consistent with the speciation of the solution. The ligand phosphorescence band for this sample is identical to the one exhibited by the Gd sample. From these spectra, the 0 -phonon energy of the triplet state of the bound ligand can be estimated to be $21,600 \mathrm{~cm}^{-1}$, while the 0 -phonon energy of the singlet state lies at about $26,000 \mathrm{~cm}^{-1}$, as estimated

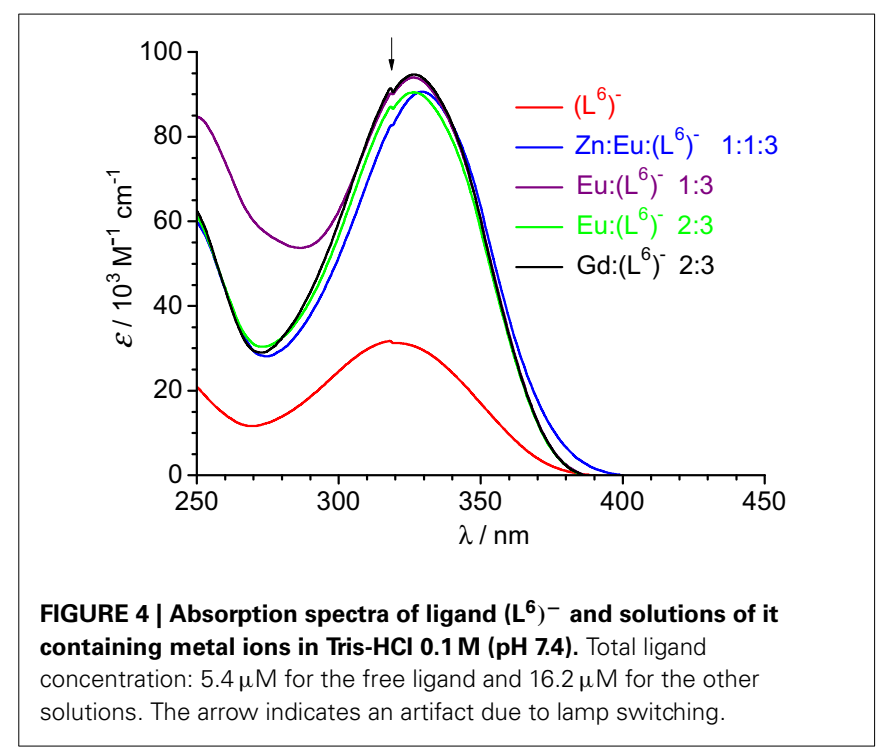

Table 3 | Photophysical data of the free and coordinated $\left(\mathrm{L}^{6}\right)^{-}$ligand at $298 \mathrm{~K}$ in Tris- $\mathrm{HCl}\left(\mathrm{pH}\right.$ 7.4). Energies are reported in $\mathrm{cm}^{-1}$.

\begin{tabular}{llllll}
\hline & ${\left(\mathbf{L}^{\mathbf{6}}\right)^{-}}$ & $\begin{array}{l}\mathbf{E u}:\left(\mathbf{L}^{\mathbf{6}}\right)^{-} \\
\mathbf{1 : 3}\end{array}$ & $\begin{array}{l}\mathbf{G d :}\left(\mathbf{L}^{\mathbf{6}}\right)^{-} \\
\mathbf{1 : 3}\end{array}$ & $\begin{array}{l}\mathbf{E u}:\left(\mathbf{L}^{\mathbf{6}}\right)^{-} \\
\mathbf{2 : 3}\end{array}$ & $\begin{array}{l}\mathbf{Z n}: \mathrm{Eu}:\left(\mathbf{L}^{\mathbf{6}}\right)^{-} \\
\mathbf{1 : 1 : 3}\end{array}$ \\
\hline$E\left({ }^{*} \pi \leftarrow \pi\right)^{a}$ & 31,450 & 30,630 & 30,580 & 30,630 & 30,350 \\
$\log \varepsilon$ & 4.50 & 4.97 & 4.98 & 4.96 & 4.96 \\
$E\left(1 \pi \pi^{*}\right)^{b}$ & 21,450 & 22,350 & 22,350 & 22,450 & 21,950 \\
\hline
\end{tabular}

${ }^{a}$ From absorption spectra, maximum of band envelope.

${ }^{b}$ From fluorescence spectra, maximum of band envelope.

from the onset of the fluorescence band. These energies are close to those reported for $\left(\mathrm{L}^{\mathrm{C} 2}\right)^{2-}$ (Chauvin et al., 2008) and are adequate for ensuring efficient intersystem crossing and energy transfer onto the ${ }^{5} \mathrm{D}_{1}\left(19,030 \mathrm{~cm}^{-1}\right)$ and ${ }^{5} \mathrm{D}_{0}\left(17,230 \mathrm{~cm}^{-1}\right)$ levels of $\mathrm{Eu}^{\mathrm{III}}$; on the other hand the quasi resonance between ${ }^{3} \pi \pi^{*}$ and ${ }^{5} \mathrm{D}_{2} \quad\left(21,500 \mathrm{~cm}^{-1}\right)$ may generate some back energy transfer. 

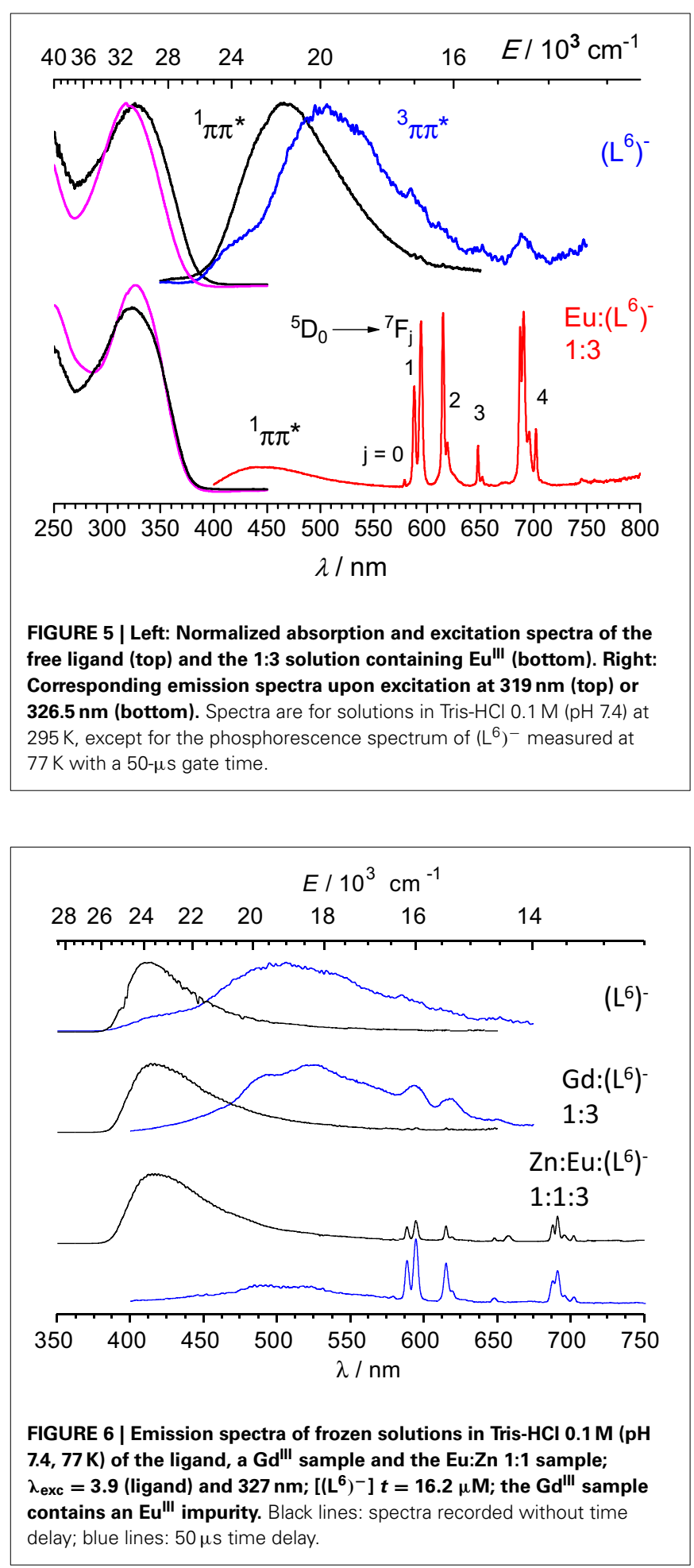

Lifetimes and quantum yields of the $\mathrm{Eu}\left({ }^{5} \mathrm{D}_{0}\right)$ level are reported in Table 4. Despite the different speciation of the solutions, the luminescence decays can be fitted with monoexponential functions and the resulting lifetimes lie within a narrow range, 2.46-2.69 ms, the shortest figure corresponding to the solution with the largest concentration of the 2:3 (or 1:1:3) species, in line with the somewhat shorter lifetime reported for $\left[\mathrm{Eu}_{2}\left(\mathrm{~L}^{\mathrm{Ci}}\right)_{3}\right]$, $2.43 \mathrm{~ms}$ for $\mathrm{i}=1$ (Elhabiri et al., 1999) and 2 (Chauvin et al., 2008) under similar experimental conditions. At low temperature, the lifetimes are much longer, pointing to temperaturedependent quenching mechanism(s) operating, e.g., back transfer (see above) or photo-induced electron transfer (PET). The radiative lifetimes can be estimated from the following equation:

$$
\tau_{\mathrm{rad}}=\frac{1}{A_{\mathrm{MD}, 0} \cdot n^{3}} \times\left(\frac{I_{\mathrm{MD}}}{I_{\mathrm{tot}}}\right)
$$

where $A_{\mathrm{MD}, 0}=14.65 \mathrm{~s}^{-1}$ is the decay rate of the magnetic dipole ${ }^{5} \mathrm{D}_{0} \rightarrow{ }^{7} \mathrm{~F}_{1}$ transition, $n$ is the refractive index of the medium, and $I_{\mathrm{MD}}$ and $I_{\text {tot }}$ are the integrated emission areas of the ${ }^{5} \mathrm{D}_{0} \rightarrow{ }^{7} \mathrm{~F}_{1}$ and ${ }^{5} \mathrm{D}_{0} \rightarrow{ }^{7} \mathrm{~F}_{J}(J=0-6)$ transitions. The corresponding data lead to evaluation of the intrinsic quantum yield, i.e., the quantum yield upon direct excitation onto the ${ }^{5} \mathrm{D}_{0}$ level, since it is very difficult to determine experimentally in view of the faint molar absorption coefficients of the f-f transitions. The sensitization efficiency of the ligand can subsequently be calculated:

$$
Q_{\mathrm{Eu}}^{\mathrm{Eu}}=\frac{\tau_{\mathrm{obs}}}{\tau_{\mathrm{rad}}}, \quad \eta_{\text {sens }}=\frac{Q_{\mathrm{Eu}}^{L}}{Q_{\mathrm{Eu}}^{\mathrm{Eu}}}
$$

Both sets of data, radiative lifetimes and intrinsic quantum yields, are consistent for the three samples and, moreover they compare very well with data reported for the $\left[\mathrm{Eu}_{2}\left(\mathrm{~L}^{\mathrm{Cl}}, 2\right)_{3}\right]$ helicates: $\tau_{\text {rad }}=6.8-6.9 \pm 0.3 \mathrm{~ms}$ and $Q_{\mathrm{Eu}}^{\mathrm{Eu}}=36-37 \pm 4 \%$ (Bünzli et al., 2008). On the other hand, absolute quantum yields and sensitization efficiencies are about three-fold smaller compared to the reference helicates $\left(Q_{\mathrm{Eu}}^{L}=21-24 \%, \eta_{\text {sens }}=58-67 \%\right)$ due to the non-quantitative formation of the species. It is however noteworthy that the quantum yields of the two solutions containing $\mathrm{Eu}^{\mathrm{III}}$ only, which feature approximately the same concentration of $\mathrm{EuN}_{6} \mathrm{O}_{3}$ sites $(79$ and $73 \%$ for $1: 2$ and 2:3 stoichiometric ratios, respectively), are equal, within experimental errors. For the heterometallic solution, the quantum yield is smaller, due to the small concentration of the 1:1:3 species, which, in addition features only one $\mathrm{EuN}_{6} \mathrm{O}_{3}$ coordination site.

\section{CONCLUSION}

Reaction of ligands $\mathrm{HL}^{5}$ and $\mathrm{HL}^{6}$ (Scheme 3) under physiological conditions with equimolar quantities of $\mathrm{Zn}^{\mathrm{II}}$ and $\mathrm{Ln}^{\mathrm{III}}$ ions did not lead to a thermodynamically controlled assembly of the desired 3d-4f helicates, as expected from work with $\mathrm{HL}^{4}$, the 1:1:3 complex representing only $40 \%$ of the speciation. This can be traced back to stability of the $\mathrm{Zn}^{\mathrm{II}}$ complexes with these ligands, even with respect to coordination to the tridentate unit, which is close to that of the $\mathrm{Ln}^{\mathrm{III}}$ complexes. Attempts to isolate solid state samples of the helicates with transition metal ions such as $\mathrm{Zn}^{\mathrm{II}}, \mathrm{Cr}^{\mathrm{III}}, \mathrm{Ru}^{\mathrm{II}}$ also afforded mixtures which we did not succeed to purify to an acceptable level. There is no doubt that the NNO moiety of the ligand should be remodeled to get better recognition of the $\operatorname{Ln}^{\mathrm{III}}$ ions. An encouraging aspect, however, is that all luminescent data gathered for $\mathrm{Eu}^{\mathrm{III}}$ solutions with different compositions point to the formation of either $1: 3$ or $2: 3$, or 1:1:3 
Table 4 | Observed and radiative lifetimes $(\tau)$,intrinsic and absolute quantum yields $(Q)$ of the $\mathrm{Eu}\left({ }^{5} \mathrm{D}_{0}\right)$ level, as well as apparent ligand sensitization ( $\eta_{\text {sens }}$ ) for various samples in Tris- $\mathrm{HCl} 0.1 \mathrm{M}(\mathrm{pH} 7.4)$ with $\left[\left(\mathrm{L}^{6}\right)^{-}\right]_{t}=16.2 \mu \mathrm{M}$, as determined at $298 \mathrm{~K}$ under ligand excitation $(326-329 \mathrm{~nm})$.

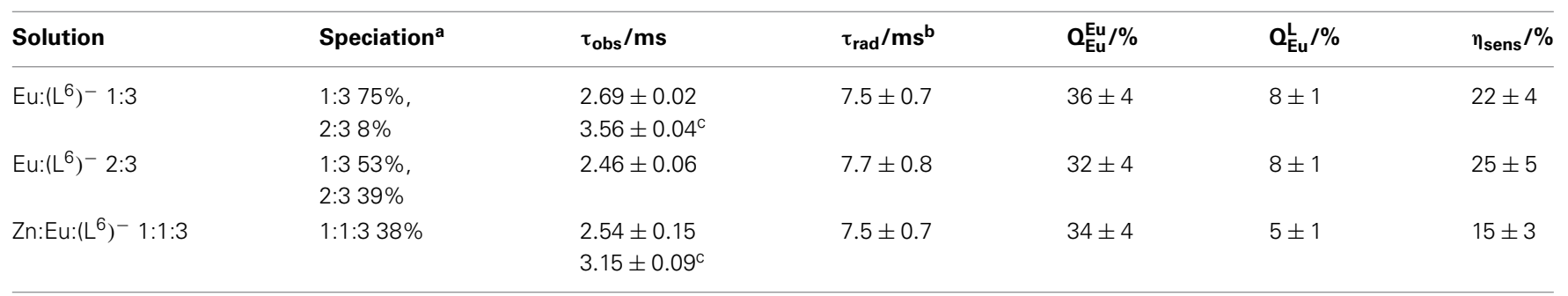

${ }^{a}$ From Figure 2.

${ }^{b}$ Calculated with eq. (6).

${ }^{c}$ In frozen solution at $77 \mathrm{~K}$.

complexes in which the lanthanide ion is coordinated to the tridentate chelating unit of ligand $\mathrm{HL}^{6}$, a judged by the crystal field splitting and other photophysical parameters which reflect the peculiar signature of the $\mathrm{Eu}(\mathrm{NNO})_{3}$ environment. In particular, the radiative lifetimes and intrinsic quantum yields match those of the previously reported helicates $\left[\mathrm{Eu}_{2}\left(\mathrm{~L}^{\mathrm{Cl}}\right)_{3}\right]$ and $\left[\mathrm{Eu}_{2}\left(\mathrm{~L}^{\mathrm{C} 2}\right)_{3}\right]$ with bis(tridentate) ligands.

On the other hand, the synthetic strategy applied for the preparation of tridentate-bidentate compartmental ligands aimed at assembling $3 \mathrm{~d}-4 \mathrm{f}$ binuclear complexes proved to be valuable in that the ligands are obtained in reasonable yields given the number of steps needed. Moreover, the strategy can be adapted to graft other substituents on the sulfonate groups through modification of the key building block $\mathbf{6}$ (Scheme 2), so that this class of ligands represent a valuable addition to the chemistry of $3 \mathrm{~d}-4 \mathrm{f}$ complexes.

\section{MATERIALS AND METHODS SYNTHESIS OF THE LIGANDS}

Sulfonation of 2-picoline (Delarge, 1965) and bromination of TEGOMe (Deiters et al., 2009) have been previously reported so that these steps are not described here, except for NMR and ESI-MS characterization of (3). Substituted pyridines (7) and (9) (Li et al., 2008; Deiters et al., 2009) and bis-( $\mathrm{N}$ methylamino)diphenylmethane (8) (Piguet et al., 1992) were prepared according to literature procedures.

\section{Starting materials and general procedures}

Chemicals and solvents were purchased from Fluka A.G or Aldrich. Solvents were purified by passing them through activated alumina columns from Innovative Technology Inc. (Pangborn et al., 1996). Complexes were studied in solution only. Stock solutions of lanthanides were prepared just before use in freshly boiled, doubly distilled water from the corresponding $\mathrm{Ln}\left(\mathrm{ClO}_{4}\right)_{3} \cdot \mathrm{xH}_{2} \mathrm{O}$ salts $(\mathrm{Ln}=\mathrm{La}, \mathrm{Eu}, \mathrm{Gd}, \mathrm{Lu} ; x=2.5-4.5)$. These salts were prepared from their oxides (Rhône-Poulenc, 99.99\% and Catalysis or Research Chemicals, Phoenix, AZ) in the usual way (Bünzli and Mabillard, 1986). The concentrations of the solutions were determined by complexometric titrations using a standardized $\mathrm{Na}_{2} \mathrm{H}_{2}$ EDTA in urotropine buffered medium and with xylenol orange as indicator (Schwarzenbach, 1957).

\section{N-benzyl-2-[2-(2-methoxyethoxy)ethoxy]-N-\{2-[2-(2-methoxyethoxy) ethoxy]ethyl\}-ethanamine (1)}

Benzylamine $\quad(2.5 \mathrm{~g}, \quad 23.3 \mathrm{mmol}), \quad$ 1-bromo-2-[2- $(2-$ methoxyethoxy)ethoxy]-ethane (11.59g, $51.3 \mathrm{mmol})$ and $\mathrm{Na}_{2} \mathrm{CO}_{3}(5.44 \mathrm{~g}, 51.3 \mathrm{mmol})$ were heated and stirred in anhydrous $\mathrm{CH}_{3} \mathrm{CN}(30 \mathrm{~mL})$ under inert atmosphere at $62^{\circ} \mathrm{C}$ for $76 \mathrm{~h}$. After cooling, the reaction mixture was filtered and the white precipitate of $\mathrm{Na}_{2} \mathrm{CO}_{3}$ was washed with $\mathrm{Et}_{2} \mathrm{O}$ (about $50 \mathrm{~mL}$ ). The resultant solution was evaporated under reduced pressure. The residue so obtained was re-dissolved in a hydrochloric acid solution $(50 \mathrm{~mL}, 2 \mathrm{M})$ and extracted with $\mathrm{Et}_{2} \mathrm{O}(250 \mathrm{~mL})$. The $\mathrm{pH}$ of the aqueous phase was then increased by addition of $\mathrm{NaHCO}_{3}$ up to saturation and the resulting solution was extracted with $\mathrm{Et}_{2} \mathrm{O}$ $(3 \times 250 \mathrm{~mL})$. The three organic phases were combined, dried over $\mathrm{Na}_{2} \mathrm{SO}_{4}$, filtered, and concentrated under reduced pressure. The crude material was purified by column chromatography (silica gel, $\mathrm{CH}_{2} \mathrm{Cl}_{2} / \mathrm{MeOH}$ 100:0 $\rightarrow$ 97:3) to give pale yellow oil (6.32 g, 68\% yield). ${ }^{1} \mathrm{H} \mathrm{NMR}\left(400 \mathrm{MHz}, 298 \mathrm{~K}, \mathrm{CD}_{3} \mathrm{CN}\right) \delta$ (ppm): $2.66\left(\mathrm{t},{ }^{3} \mathrm{~J}=6.2 \mathrm{~Hz}, 4 \mathrm{H}, \mathrm{NCH}_{2} \mathrm{CH}_{2}\right), 3.28\left(\mathrm{~s}, 6 \mathrm{H}, \mathrm{OCH}_{3}\right), 3.44$ $\left(\mathrm{m}, 4 \mathrm{H}, \mathrm{OCH}_{2}\right), 3.48-3.54\left(\mathrm{~m}, 16 \mathrm{H}, \mathrm{OCH}_{2}\right), 3.67\left(\mathrm{~s}, 2 \mathrm{H}, \mathrm{CH}_{2}\right)$, $7.24\left(\mathrm{~m} .1 \mathrm{H}, \mathrm{H}_{\mathrm{Ph} .}\right), 7.30\left(\mathrm{~m}, 2 \mathrm{H}, \mathrm{H}_{\mathrm{Ph}}\right), 7.33\left(\mathrm{~m}, 2 \mathrm{H}, \mathrm{H}_{\mathrm{Ph}}\right) .{ }^{13} \mathrm{C}$ NMR $\left(800 \mathrm{MHz}, 298 \mathrm{~K}, \mathrm{CDCl}_{3}\right) \delta(\mathrm{ppm}): 53.86\left(\mathrm{NCH}_{2} \mathrm{CH}_{2} \mathrm{O}\right)$, $59.20\left(\mathrm{OCH}_{3}\right), 59.86\left(\mathrm{CH}_{2}\right), 70.00\left(\mathrm{OCH}_{2}\right), 70.49\left(\mathrm{OCH}_{2}\right)$, $70.68\left(\mathrm{OCH}_{2}\right), 70.78\left(\mathrm{OCH}_{2}\right), 72.06\left(\mathrm{OCH}_{2}\right), 126.96\left(\mathrm{CH}_{\mathrm{Ph}}\right)$, $128.27\left(\mathrm{CH}_{\mathrm{Ph} .}\right), 128.97\left(\mathrm{CH}_{\mathrm{Ph}}\right), 139.85\left(\mathrm{C}_{\mathrm{Ph}}\right.$.quat. $)$. ESI-MS $\mathrm{m} / \mathrm{z}$ calcd for $\left[\mathrm{M}+\mathrm{H}^{+}\right]$(found): 400.27 (400.04).

\section{2-[2-(2-methoxyethoxy)ethoxy]-N-\{2-[2-(2-methoxyethoxy)ethoxy] ethyl\}ethanamine (2)}

Continuous flow hydrogenation of an ethanolic solution $(0.05 \mathrm{M}$, $250 \mathrm{~mL}$ ) of (1) (5.00 g, $12.5 \mathrm{mmol})$ was conducted with a safety HCube device from Thales Nanotechnology equipped with a HPLC pump under the following conditions; flow rate: $1 \mathrm{~mL} / \mathrm{min}$, catalyst cartridge: $\mathrm{Pd} / \mathrm{C} ; \mathrm{H}_{2}$ pressure: 70 bar; temperature: $45^{\circ} \mathrm{C}$. Ethanol and generated toluene were removed under reduced pressure and (2) obtained as a yellow oil was subsequently dried under vacuum $(3.87 \mathrm{~g}, 100 \%$ yield). Note: one run was enough to fully convert (1) into (2) under the conditions mentioned above. ${ }^{1} \mathrm{H}$ NMR $\left(400 \mathrm{MHz}, 298 \mathrm{~K}, \mathrm{CD}_{3} \mathrm{CN}\right) \delta(\mathrm{ppm}): 2.73\left(\mathrm{t},{ }^{3} \mathrm{~J}=6.2 \mathrm{~Hz}\right.$, $\left.4 \mathrm{H}, \mathrm{NCH}_{2} \mathrm{CH}_{2}\right), 3.30\left(\mathrm{~s}, 6 \mathrm{H}, \mathrm{OCH}_{3}\right), 3.46-3.57\left(\mathrm{~m}, 20 \mathrm{H}, \mathrm{OCH}_{2}\right)$. ${ }^{13} \mathrm{C} \mathrm{NMR}\left(800 \mathrm{MHz}, 298 \mathrm{~K}, \mathrm{CDCl}_{3}\right) \delta(\mathrm{ppm}): 49.30\left(\mathrm{NCH}_{2} \mathrm{CH}_{2}\right)$, 
$59.21\left(\mathrm{OCH}_{3}\right), 70.47\left(\mathrm{OCH}_{2}\right), 70.63\left(\mathrm{OCH}_{2}\right), 70.65\left(\mathrm{OCH}_{2}\right)$, $70.67\left(\mathrm{OCH}_{2}\right), 72.05\left(\mathrm{OCH}_{2}\right)$. ESI-MS $m / z$ calcd for $\left[\mathrm{M}+\mathrm{H}^{+}\right]$ (found): 310.23 (309.94).

\section{6-methylpyridinium-3-sulfonate (3)}

This compound was synthetized according to a procedure described in the literature (Delarge, 1965); NMR and ESI-MS data are however reported here for the first time. ${ }^{1} \mathrm{H}$ NMR $\left(400 \mathrm{MHz}, 298 \mathrm{~K}, \mathrm{D}_{2} \mathrm{O}\right) \delta(\mathrm{ppm}): 2.81\left(\mathrm{~s}, 3 \mathrm{H}, \mathrm{CH}_{3}\right), 7.97$ (d, $\left.{ }^{3} J=8.5 \mathrm{~Hz}, 1 \mathrm{H}, \mathrm{H}_{\text {Py. }}\right), 8.69\left(\mathrm{~d},{ }^{3} \mathrm{~J}=8.5 \mathrm{~Hz}, 1 \mathrm{H}, \mathrm{H}_{\text {Py. }}\right), 8.97$ (s, 1H, H Py. $){ }^{13} \mathrm{C}$ NMR $\left(800 \mathrm{MHz}, 298 \mathrm{~K}, \mathrm{D}_{2} \mathrm{O}\right) \delta$ (ppm): 19.15 $\left(\mathrm{CH}_{3}\right), 128.55\left(\mathrm{CH}_{\text {Py. }}\right), 138.35\left(\mathrm{CH}_{\text {Py. }}\right), 140.16$ (C $\mathrm{Cy}$. quat. $), 142.95$ $\left(\mathrm{CH}_{\mathrm{Py}}\right.$ ), 156.86 ( $\mathrm{C}_{\mathrm{Py}}$ quat. $)$. ESI-MS $\mathrm{m} / z$ calcd for $\left[\mathrm{M}+\mathrm{H}^{+}\right]$ (found): 174.02 (173.91); calcd for $\left[\mathrm{M}+\mathrm{CH}_{3} \mathrm{CN}+\mathrm{H}^{+}\right]$(found): 215.05 (214.87).

\section{6-methylpyridinium-3-sulfonyl chloride (4)}

Synthon (3) $(1.00 \mathrm{~g}, 5.78 \mathrm{mmol})$ and $\mathrm{PCl}_{5}(1.91 \mathrm{~g}, 9.25 \mathrm{mmol})$ were suspended in $\mathrm{POCl}_{3}(5 \mathrm{~mL})$ and stirred at room temperature for $48 \mathrm{~h}$. Then, $\mathrm{POCl}_{3}$ was rotor-evaporated and the residue was dissolved in $\mathrm{CH}_{2} \mathrm{Cl}_{2}(25 \mathrm{~mL})$. Crushed ice (about $5 \mathrm{~g}$ ) was slowly added to this solution (beware, the reaction is highly exothermic!) and the resulting phases were separated. The aqueous phase was extracted with $\mathrm{CH}_{2} \mathrm{Cl}_{2}(3 \times 50 \mathrm{~mL})$. The combined organic phases were combined, washed with dilute $\mathrm{NaHCO}_{3}$ solution, dried over $\mathrm{Na}_{2} \mathrm{SO}_{4}$, filtered and concentrated under reduced pressure. The crude material was charged and eluted on a chromatography column (silica gel, $\mathrm{Et}_{2} \mathrm{O} /$ petroleum ether 50:50 $\rightarrow$ 90:10) to give a white solid $\left(0.766 \mathrm{~g}, 70 \%\right.$ yield). ${ }^{1} \mathrm{H}$ NMR $(400 \mathrm{MHz}$, $\left.298 \mathrm{~K}, \mathrm{CDCl}_{3}\right) \delta(\mathrm{ppm}): 2.73\left(\mathrm{~s}, 3 \mathrm{H}, \mathrm{CH}_{3}\right), 7.42\left(\mathrm{~d},{ }^{3} \mathrm{~J}=8.5 \mathrm{~Hz}\right.$, $1 \mathrm{H}, \mathrm{H}_{\mathrm{Py}}$ ), 8.18 (dd, $\left.{ }^{3} \mathrm{~J}=8.5 \mathrm{~Hz},{ }^{4} J=2.3 \mathrm{~Hz}, 1 \mathrm{H}, \mathrm{H}_{\mathrm{Py}}\right), 9.12(\mathrm{~d}$, $\left.{ }^{4} J=2.3 \mathrm{~Hz}, 1 \mathrm{H}, \mathrm{H}_{\mathrm{Py}}\right){ }^{13} \mathrm{C} \mathrm{NMR}\left(800 \mathrm{MHz}, 298 \mathrm{~K}, \mathrm{DMSO}-d_{6}\right)$ $\delta$ (ppm): $19.36\left(\mathrm{CH}_{3}\right), 127.68\left(\mathrm{CH}_{\text {Py. }}\right), 138.23\left(\mathrm{CH}_{\text {Py. }}\right), 142.49$ $\left(\mathrm{CH}_{\mathrm{Py}}\right.$ ), 144.30 ( $\left.\mathrm{C}_{\text {Py. quat. }}\right), 154.30$ ( $\left.\mathrm{C}_{\text {Py. quat. }}\right)$. ESI-MS $m / z$ calcd for $\left[\mathrm{M}+\mathrm{H}^{+}\right]$(found): 191.99 (191.81).

\section{N,N-bis\{2-[2-(2-methoxyethoxy)ethoxy]ethyl\}-6-methylpyridine-3- sulfonamide (5)}

Compound (4) (0.900 g, $4.71 \mathrm{mmol}$ ) was dissolved in dry $\mathrm{CH}_{2} \mathrm{Cl}_{2}$ (about $20 \mathrm{~mL}$ ) under $\mathrm{N}_{2}$ steam and $3.3 \mathrm{~mL} \mathrm{NEt}_{3}(23.6 \mathrm{mmol})$ was added. The resulting solution was refluxed and a solution of $\mathrm{CH}_{2} \mathrm{Cl}_{2}$ containing (2) (1.75 g, $5.66 \mathrm{mmol}$ ) was added dropwise. The reflux was subsequently maintained for $16 \mathrm{~h}$. After cooling, the solvent and excess of $\mathrm{NEt}_{3}$ were rotor-evaporated under reduced pressure. The residue was dissolved in $\mathrm{CH}_{2} \mathrm{Cl}_{2}$ $(50 \mathrm{~mL})$ and a saturated aqueous solution of $\mathrm{NH}_{4} \mathrm{Cl}(50 \mathrm{~mL})$ was added. After separation, the aqueous phase was extracted with $3 \times 50 \mathrm{~mL} \mathrm{CH} \mathrm{Cl}_{2}$. The combined organic phases were reduced to a volume of about $100 \mathrm{~mL}$. This solution was dried over $\mathrm{Na}_{2} \mathrm{SO}_{4}$, filtered, and evaporated under reduced pressure. The crude material was purified by column chromatography (silica gel, $\mathrm{CH}_{2} \mathrm{Cl}_{2} / \mathrm{MeOH}$ 100:0 $\rightarrow$ 97:3) to afford amber oil (1.81 g, $83 \%$ yield). ${ }^{1} \mathrm{H}$ NMR ( $\left.400 \mathrm{MHz}, 298 \mathrm{~K}, \mathrm{CD}_{3} \mathrm{CN}\right) \delta(\mathrm{ppm}): 2.58$ $\left(\mathrm{s}, 3 \mathrm{H}, \mathrm{CH}_{3}\right), 3.28\left(\mathrm{~s}, 6 \mathrm{H}, \mathrm{OCH}_{3}\right), 3.40\left(\mathrm{~m}, 4 \mathrm{H}, \mathrm{OCH}_{2} \mathrm{CH}_{2}\right)$, $3.44-3.57\left(\mathrm{~m}, 20 \mathrm{H}, \mathrm{OCH}_{2}\right), 7.37$ (d, ${ }^{3} \mathrm{~J}=8.2 \mathrm{~Hz}, 1 \mathrm{H}, \mathrm{H}_{\mathrm{Py}}$ ) $), 8.03$ $\left(\mathrm{dd},{ }^{3} J=8.2 \mathrm{~Hz},{ }^{4} J=2.4 \mathrm{~Hz}, 1 \mathrm{H}, \mathrm{H}_{\mathrm{Py}}\right), 8.86\left(\mathrm{~d},{ }^{4} J=2.4 \mathrm{~Hz}\right.$, $\left.1 \mathrm{H}, \mathrm{H}_{\text {Py. }}\right){ }^{13} \mathrm{C} \mathrm{NMR}\left(800 \mathrm{MHz}, 298 \mathrm{~K}, \mathrm{CDCl}_{3}\right) \delta(\mathrm{ppm}): 24.79$
$\left(\mathrm{CH}_{3}\right), 48.46\left(\mathrm{NCH}_{2} \mathrm{CH}_{2}\right), 59.20\left(\mathrm{OCH}_{3}\right), 69.90\left(\mathrm{OCH}_{2}\right), 70.49$ $\left(\mathrm{OCH}_{2}\right), 70.62\left(\mathrm{OCH}_{2}\right), 70.67\left(\mathrm{OCH}_{2}\right), 72.04\left(\mathrm{OCH}_{2}\right), 123.35$ $\left(\mathrm{CH}_{\text {Py. }}\right), 134.04$ ( $\left.\mathrm{C}_{\text {Py. quat. }}\right), 135.33\left(\mathrm{CH}_{\text {Py. }}\right), 147.71\left(\mathrm{CH}_{\text {Py. }}\right)$, 162.94 ( (Py. quat. $_{\text {. }}$. ESI-MS $\mathrm{m} / z$ calcd for $\left[\mathrm{M}+\mathrm{H}^{+}\right]$(found): 465.23 (465.00); calcd for [ $\left.\mathrm{M}+\mathrm{Na}^{+}\right]$(found): 487.01 (487.21).

\section{5-(bis\{2-[2-(2-methoxyethoxy)ethoxy]ethyl\}sulfamoyl)pyridine-2- carboxylic acid (6)}

Compound (5) (1.80 g, $3.88 \mathrm{mmol})$ was added to a suspension of $\mathrm{SeO}_{2}$ (1.94 g, $\left.17.45 \mathrm{mmol}\right)$ in dry pyridine $(60 \mathrm{~mL})$ maintained under an $\mathrm{N}_{2}$ stream. The heterogeneous mixture was refluxed for $24 \mathrm{~h}$ and filtered through Celite ${ }^{\circledR}$ after cooling. Celite ${ }^{\circledR}$ was further washed with $\mathrm{Et}_{2} \mathrm{O}$ (about $100 \mathrm{~mL}$ ) and the solvents were removed under reduced pressure. The residue was dissolved in distilled $\mathrm{H}_{2} \mathrm{O}$ (about $20 \mathrm{~mL}$ ) and the $\mathrm{pH}$ was increased to 10 by addition of aqueous $\mathrm{NaOH}(5 \%)$. The aqueous phase was then extracted with $\mathrm{CH}_{2} \mathrm{Cl}_{2}(3 \times 100 \mathrm{~mL})$. The aqueous phase was acidified to $\mathrm{pH} 3$ by adding aqueous hydrochloric acid (25\%) and the resulting solution was extracted again with $\mathrm{CH}_{2} \mathrm{Cl}_{2}(3 \times 100 \mathrm{~mL})$. The organic phases were combined, reduced to a volume of about $100 \mathrm{~mL}$, dried over $\mathrm{Na}_{2} \mathrm{SO}_{4}$, filtered, and rotor-evaporated under reduced pressure. After drying, (6) was obtained as an amber oil $\left(1.83 \mathrm{~g}, 96 \%\right.$ yield). ${ }^{1} \mathrm{H}$ NMR $\left(400 \mathrm{MHz}, 298 \mathrm{~K}\right.$, acetone- $\left.d_{6}\right)$ $\delta$ (ppm): $3.29\left(\mathrm{~s}, 6 \mathrm{H}, \mathrm{OCH}_{3}\right), 3.45-3.49\left(\mathrm{~m}, 12 \mathrm{H}, \mathrm{OCH}_{2}\right), 3.54$ $\left(\mathrm{m}, 4 \mathrm{H}, \mathrm{OCH}_{2}\right), 3.58\left(\mathrm{~m}, 4 \mathrm{H}, \mathrm{OCH}_{2}\right), 3.64\left(\mathrm{~m}, 4 \mathrm{H}, \mathrm{OCH}_{2}\right), 8.32$ $\left(\mathrm{d},{ }^{3} \mathrm{~J}=8.1 \mathrm{~Hz}, 1 \mathrm{H}, \mathrm{H}_{\mathrm{Py}}\right), 8.50\left(\mathrm{dd},{ }^{3} \mathrm{~J}=8.1 \mathrm{~Hz},{ }^{4} \mathrm{~J}=2.2 \mathrm{~Hz}\right.$, $\left.1 \mathrm{H}, \mathrm{H}_{\mathrm{Py}}\right), 9.09\left(\mathrm{~d},{ }^{4} \mathrm{~J}=2.2 \mathrm{~Hz}, 1 \mathrm{H}, \mathrm{H}_{\mathrm{Py}}\right){ }^{13} \mathrm{C} \mathrm{NMR}(800 \mathrm{MHz}$, $\left.298 \mathrm{~K}, \mathrm{CDCl}_{3}\right) \delta(\mathrm{ppm}): 47.71\left(\mathrm{NCH}_{2} \mathrm{CH}_{2}\right), 59.16\left(\mathrm{OCH}_{3}\right), 67.21$ $\left(\mathrm{OCH}_{2}\right), 69.37\left(\mathrm{OCH}_{2}\right), 70.46\left(\mathrm{OCH}_{2}\right), 70.57\left(\mathrm{OCH}_{2}\right), 72.06$ $\left(\mathrm{OCH}_{2}\right), 123.97\left(\mathrm{CH}_{\mathrm{Py}}\right), 137.71\left(\mathrm{CH}_{\mathrm{Py}}\right), 141.33\left(\mathrm{CH}_{\mathrm{Py}}\right), 147.19$ $\left(\mathrm{CH}_{\text {Py. }}\right), 148.35$ ( $\left.\mathrm{C}_{\text {Py. quat. }}\right), 163.18(\mathrm{COOH})$. ESI-MS $\mathrm{m} / \mathrm{z}$ calcd for $\left[\mathrm{M}+\mathrm{H}^{+}\right]$(found): 495.20 (495.00).

\section{Ethyl 6-(methyl\{4-[4-(methylamino)-3-nitrobenzyl]-2-nitrophenyl\} carbamoyl)pyridine-2-carboxylate (10)}

A mixture of 2,6-pyridinecarboxylic acid monoethyl ester (7) ( $1.00 \mathrm{~g}, 5.13 \mathrm{mmol})$, freshly distilled $\mathrm{SOCl}_{2}(6.10 \mathrm{~g}, 51.3 \mathrm{mmol})$, and dry DMF $(200 \mu \mathrm{L}, 2.56 \mathrm{mmol})$ were refluxed in dry $\mathrm{CH}_{2} \mathrm{Cl}_{2}$ $(50 \mathrm{~mL})$ under an inert atmosphere for $2 \mathrm{~h}$. After evaporation and pumping for $2 \mathrm{~h}$, the pale yellow solid formed was re-dissolved in dry $\mathrm{CH}_{2} \mathrm{Cl}_{2}(50 \mathrm{~mL})$. 3,3'-dinitro-4,4'-bis $(N$ methylamino)diphenylmethane (8) $(1.46 \mathrm{~g}, 4.61 \mathrm{mmol})$ and $\mathrm{NEt}_{3}$ $(2.00 \mathrm{~mL})$ were added to this solution. The resulting mixture was refluxed for $16 \mathrm{~h}$ and evaporated. The red-brown residue was redissolved in $\mathrm{CH}_{2} \mathrm{Cl}_{2}(100 \mathrm{~mL})$ and washed with half-saturated $\mathrm{NH}_{4} \mathrm{Cl}$ solution $(100 \mathrm{~mL})$. After separation, the aqueous phase was extracted with $\mathrm{CH}_{2} \mathrm{CL}_{2}(2 \times 100 \mathrm{~mL})$. The combined organic phases were dried over $\mathrm{Na}_{2} \mathrm{SO}_{4}$ and evaporated. The resulting red-brown solid was purified by column chromatography (silica gel, $\mathrm{CH}_{2} \mathrm{Cl}_{2} /$ hexane 95:5 $\rightarrow \mathrm{CH}_{2} \mathrm{Cl}_{2} / \mathrm{MeOH}$ 99:1) to give the mono-substituted product $(\mathbf{1 0})$ as orange solid $(1.09 \mathrm{~g}, 48 \%$ yield). ${ }^{1} \mathrm{H}$ NMR $\left(400 \mathrm{MHz}, 433 \mathrm{~K}, \mathrm{DMSO}-d_{6}\right) \delta$ (ppm): 1.30 $\left(\mathrm{t},{ }^{3} \mathrm{~J}=7.2 \mathrm{~Hz}, 3 \mathrm{H}, \mathrm{OCH}_{2} \mathrm{CH}_{3}\right), 3.00\left(\mathrm{~d},{ }^{3} \mathrm{~J}=5.1 \mathrm{~Hz}, 3 \mathrm{H}\right.$, $\left.\mathrm{NHCH}_{3}\right), 3.41\left(\mathrm{~s}, 3 \mathrm{H}, \mathrm{NCH}_{3}\right), 4.00\left(\mathrm{~s}, 2 \mathrm{H}, \mathrm{CH}_{2}\right), 4.25\left(\mathrm{q},{ }^{3} \mathrm{~J}=\right.$ $\left.7.2 \mathrm{~Hz}, 2 \mathrm{H}, \mathrm{OCH}_{2} \mathrm{CH}_{3}\right), 6.95\left(\mathrm{~d},{ }^{3} \mathrm{~J}=8.7 \mathrm{~Hz}, 1 \mathrm{H}, \mathrm{H}_{\text {Benz. }}\right), 7.36$ $\left(\mathrm{d},{ }^{3} J=8.7 \mathrm{~Hz}, 1 \mathrm{H}, \mathrm{H}_{\text {Benz. }}\right), 7.44\left(\mathrm{~d},{ }^{3} J=7.8 \mathrm{~Hz}, 1 \mathrm{H}, \mathrm{H}_{\text {Benz. }}\right), 7.51$ (d, ${ }^{3} J=7.8 \mathrm{~Hz}, 1 \mathrm{H}, \mathrm{H}_{\text {Benz. }}$ ), 7.69 (s (broad), $\left.1 \mathrm{H}, \mathrm{NH}\right), 7.83$ (s, $1 \mathrm{H}$, 
$\left.\mathrm{H}_{\text {Benz. }}\right), 7.84$ (d, $\left.{ }^{3} J=8.8 \mathrm{~Hz}, 1 \mathrm{H}, \mathrm{H}_{\text {Py. }}\right), 7.89\left(\mathrm{~d},{ }^{3} J=9.2 \mathrm{~Hz}\right.$, $\left.1 \mathrm{H}, \mathrm{H}_{\text {Py. }}\right), 7.91$ (s, $\left.1 \mathrm{H}, \mathrm{H}_{\text {Benz. }}\right), 7.98\left(\mathrm{dd},{ }^{3} \mathrm{~J}=9.2 \mathrm{~Hz},{ }^{3} \mathrm{~J}=\right.$ $\left.8.8 \mathrm{~Hz}, 1 \mathrm{H}, \mathrm{H}_{\mathrm{Py} .}\right) .{ }^{13} \mathrm{C} \mathrm{NMR}\left(800 \mathrm{MHz}, 327 \mathrm{~K}, \mathrm{DMSO}-d_{6}\right) \delta$ (ppm): $13.66\left(\mathrm{OCH}_{2} \mathrm{CH}_{3}\right), 29.43\left(\mathrm{NHCH}_{3}\right), 37.47\left(\mathrm{NCH}_{3}\right)$, $37.92\left(\mathrm{CH}_{2}\right), 60.73\left(\mathrm{OCH}_{2} \mathrm{CH}_{3}\right), 114.44\left(\mathrm{CH}_{\text {Benz. }}\right), 124.85$ $\left(\mathrm{CH}_{\text {Benz. }}\right), 125.16$ ( $\left.\mathrm{CH}_{\text {Benz. }}\right), 125.21\left(\mathrm{CH}_{\mathrm{Py}}\right), 126.34\left(\mathrm{CH}_{\mathrm{Py}}\right)$, $126.75\left(\mathrm{CH}_{\mathrm{Py}}\right), 130.59$ ( $\left.\left.\mathrm{C}_{\text {Benz. quat. }}\right), 131.10 \mathrm{C}_{\text {Benz. quat. }}\right), 134.45$ $\left(\mathrm{CH}_{\text {Benz. }}\right), 135.84$ ( $\left.\mathrm{C}_{\text {Benz. quat. }}\right), 137.02\left(\mathrm{CH}_{\text {Benz. }}\right), 138.32\left(\mathrm{CH}_{\mathrm{Py}}\right)$, 141.95 ( $\left.\mathrm{C}_{\text {Benz. quat. }}\right), 144.60$ ( $\left.\mathrm{C}_{\text {Benz. quat. }}\right), 145.03$ ( $\mathrm{C}_{\text {Benz. quat. }}$ ), 145.62 (C Py. quat. $\left._{1}\right), 151.96$ (C $\left.\mathrm{C}_{\text {Py. quat. }}\right), 163.57$ (CONMe), 165.49 (COOEt). ESI-MS $\mathrm{m} / z$ calcd for $\left[\mathrm{M}+\mathrm{H}^{+}\right]$(found): 494.17 (493.97); calcd for $\left[\mathrm{M}+\mathrm{Na}^{+}\right]$(found): 516.14 (515.96).

Note: The mono- $(\mathbf{1 0}, \mathbf{1 3})$ and bis- $(\mathbf{1 1}, \mathbf{1 4})$ amide intermediates display at least two different conformations at $298 \mathrm{~K}$ with enough slow exchange rates to be observed on both ${ }^{1} \mathrm{H}$ and ${ }^{13} \mathrm{C}$ NMR spectra. Thus, the NMR spectra of these compounds were recorded at higher temperature to give one set of averaged signals.

\section{Ethyl 6-[(4-\{4-[\{[5-(bis\{2-[2-(2-methoxyethoxy)ethoxy]ethyl\} sulfamoyl)pyridin-2-yl]-carbonyl\}(methyl)amino]-3-nitrobenzyl\}-2- nitrophenyl)(methyl)carbamoyl]pyridine-2-carboxylate (11)}

A mixture of (6) (700 mg, $1.42 \mathrm{mmol}$ ), freshly distilled $\mathrm{SOCl}_{2}$ $(3.37 \mathrm{~g}, 28.3 \mathrm{mmol})$, and dry DMF $(55 \mu \mathrm{L}, 0.708 \mathrm{mmol})$ were refluxed in dry $\mathrm{CH}_{2} \mathrm{Cl}_{2}(50 \mathrm{~mL})$ under an inert atmosphere for $2 \mathrm{~h}$. After evaporation and pumping for $2 \mathrm{~h}$, the brown oil formed was re-dissolved in dry $\mathrm{CH}_{2} \mathrm{Cl}_{2}(25 \mathrm{~mL})$ and $\mathrm{NEt}_{3}(2.00 \mathrm{~mL})$ was added. This mixture was refluxed and a solution of dry $\mathrm{CH}_{2} \mathrm{Cl}_{2}$ (25 mL) containing (10) (437 mg, $8.85 \mathrm{mmol}$ ) was added dropwise over a period of $30 \mathrm{~min}$. The resulting solution was kept under reflux for $16 \mathrm{~h}$. and evaporated. The brown residue was re-dissolved in $\mathrm{CH}_{2} \mathrm{Cl}_{2}(100 \mathrm{~mL})$ and washed with half-saturated $\mathrm{NH}_{4} \mathrm{Cl}$ solution $(100 \mathrm{~mL})$. After separation, the aqueous phase was extracted with $\mathrm{CH}_{2} \mathrm{Cl}_{2}(2 \times 100 \mathrm{~mL})$. The combined organic phases were dried over $\mathrm{Na}_{2} \mathrm{SO}_{4}$ and evaporated. The crude material was purified by column chromatography (silica gel, $\mathrm{CH}_{2} \mathrm{Cl}_{2} / \mathrm{MeOH}$ 99:1 $\rightarrow \mathrm{CH}_{2} \mathrm{Cl}_{2} / \mathrm{MeOH}$ 95:5) to afford brown oil (840 mg, 98\% yield). ${ }^{1} \mathrm{H}$ NMR $(400 \mathrm{MHz}, 433 \mathrm{~K}$, DMSO$\left.d_{6}\right) \delta(\mathrm{ppm}): 1.29\left(\mathrm{t},{ }^{3} \mathrm{~J}=7.2 \mathrm{~Hz}, 3 \mathrm{H}, \mathrm{OCH}_{2} \mathrm{CH}_{3}\right), 3.28(\mathrm{~s}, 6 \mathrm{H}$, $\left.\mathrm{OCH}_{3}\right), 3.40\left(\mathrm{~s}, 3 \mathrm{H}, \mathrm{NCH}_{3}\right), 3.41\left(\mathrm{~s}, 3 \mathrm{H}, \mathrm{NCH}_{3}\right), 3.41(\mathrm{~m}, 4 \mathrm{H}$, $\mathrm{NCH}_{2} \mathrm{CH}_{2}$ ), 3.46-3.61 (m, 20H, $\mathrm{OCH}_{2}$ ), 4.16 (s (broad), $2 \mathrm{H}$, $\left.\mathrm{CH}_{2}\right), 4.25\left(\mathrm{q},{ }^{3} \mathrm{~J}=7.2 \mathrm{~Hz}, 2 \mathrm{H}, \mathrm{OCH}_{2} \mathrm{CH}_{3}\right), 7.48\left(\mathrm{~d},{ }^{3} \mathrm{~J}=\right.$ $8.9 \mathrm{~Hz}, 2 \mathrm{H}, \mathrm{H}_{\text {Benz. }}$ ), 7.49 (d, ${ }^{3} J=8.9 \mathrm{~Hz}, 2 \mathrm{H}, \mathrm{H}_{\text {Benz. }}$ ), 7.80 (dd, $\left.{ }^{3} \mathrm{~J}=8.5 \mathrm{~Hz},{ }^{4} \mathrm{~J}=1.0 \mathrm{~Hz}, 1 \mathrm{H}, \mathrm{H}_{\text {Py. }}\right), 7.85\left(\mathrm{dd},{ }^{3} \mathrm{~J}=7.9 \mathrm{~Hz},{ }^{4} \mathrm{~J}\right.$ $\left.=1.0 \mathrm{~Hz}, 1 \mathrm{H}, \mathrm{H}_{\mathrm{Py}}\right), 7.86\left(\mathrm{~s}, 1 \mathrm{H}, \mathrm{H}_{\text {Benz. }}\right), 7.89$ (d, ${ }^{3} J=9.2 \mathrm{~Hz}$, $\left.1 \mathrm{H}, \mathrm{H}_{\mathrm{Py}}\right), 7.90\left(\mathrm{~s}, 1 \mathrm{H}, \mathrm{H}_{\text {Benz. }}\right), 7.99\left(\mathrm{dd},{ }^{3} \mathrm{~J}=8.5 \mathrm{~Hz},{ }^{3} \mathrm{~J}=\right.$ $7.9 \mathrm{~Hz}, 1 \mathrm{H}, \mathrm{H}_{\mathrm{Py}}$ ), 8.23 (d, $\left.{ }^{3} \mathrm{~J}=9.2 \mathrm{~Hz}, 1 \mathrm{H}, \mathrm{H}_{\mathrm{Py}}\right), 8.63(\mathrm{~s}, 1 \mathrm{H}$, $\left.\mathrm{H}_{\text {Py. }}\right) .{ }^{13} \mathrm{C}$ NMR $\left(800 \mathrm{MHz}, 327 \mathrm{~K}, \mathrm{DMSO}-d_{6}\right) \delta(\mathrm{ppm}): 13.69$ $\left(\mathrm{OCH}_{2} \mathrm{CH}_{3}\right), 37.45\left(\mathrm{NCH}_{3}\right), 38.25\left(\mathrm{NCH}_{3}\right), 47.24\left(\mathrm{NCH}_{2} \mathrm{CH}_{2}\right)$, $47.37\left(\mathrm{CH}_{2}\right), 57.82\left(\mathrm{OCH}_{3}\right), 60.75\left(\mathrm{OCH}_{2} \mathrm{CH}_{3}\right), 68.33\left(\mathrm{OCH}_{2}\right)$, $68.48\left(\mathrm{OCH}_{2}\right), 69.39\left(\mathrm{OCH}_{2}\right), 69.42\left(\mathrm{OCH}_{2}\right), 71.09\left(\mathrm{OCH}_{2}\right)$, $123.89\left(\mathrm{CH}_{\text {Benz. }}\right), 124.75$ ( $\left.\mathrm{CH}_{\text {Benz. }}\right), 124.82$ ( $\left.\mathrm{CH}_{\text {Benz. }}\right), 125.15$ $\left(\mathrm{CH}_{\mathrm{Py}}\right), 126.80\left(\mathrm{CH}_{\mathrm{Py}}\right), 131.21$ ( $\left.\mathrm{CH}_{\text {Benz. }}\right), 134.39\left(\mathrm{CH}_{\text {Benz. }}\right)$, 134.54 ( $\left.\mathrm{CH}_{\text {Benz. }}\right), 135.21$ ( $\left.\mathrm{C}_{\text {Benz. quat. }}\right), 135.77$ ( $\left.\mathrm{CH}_{\mathrm{Py}}\right), 135.87$ $\left(\mathrm{CH}_{\mathrm{Py}}\right), 136.19$ ( $\left.\mathrm{C}_{\text {Benz. quat. }}\right), 136.68\left(\mathrm{CH}_{\mathrm{Py}}\right), 138.36\left(\mathrm{CH}_{\mathrm{Py}}\right)$, 140.55 ( $\left.\mathrm{C}_{\text {Benz. quat. }}\right), 141.37$ ( $\left.\mathrm{C}_{\text {Benz. quat. }}\right), 145.02$ ( $\mathrm{C}_{\text {Benz. quat. }}$ ), 145.61 (С $\left.\mathrm{C}_{\text {Py. quat. }}\right), 145.77$ (C $\left.\mathrm{C}_{\text {Benz. quat. }}\right), 147.13$ (С $\left.\mathrm{C}_{\text {Py. quat. }}\right)$, 151.86 (С Py. quat. $_{\text {) }}, 155.07$ (Сy. quat. $), 163.61$ (CONMe.), 165.25
(CONMe), 165.42 (COOEt). ESI-MS $\mathrm{m} / z$ calcd for $\left[\mathrm{M}+\mathrm{H}^{+}\right]$ (found): 970.36 (970.20); calcd for $\left[\mathrm{M}+\mathrm{Na}^{+}\right]$(found): 992.34 (992.17).

\section{Ethyl 6-[5-(\{2-[5-(bis\{2-[2-(2-methoxyethoxy)ethoxy]ethyl\}sulfamoyl) pyridin-2-yl]-1-methyl-1H-benzimidazol-5-yl\}methyl)-1-methyl-1H- benzimidazol-2-yl]pyridine-2-carboxylate (12)}

Freshly activated iron powder $(1.41 \mathrm{~g}, 25.3 \mathrm{mmol})$ and $\mathrm{HCl}$ solution $(1.75 \mathrm{~mL}, 25 \%)$ were added to an $\mathrm{EtOH} / \mathrm{H}_{2} \mathrm{O}$ solution (165/41 mL) containing (11) $(816 \mathrm{mg}, 0.842 \mathrm{mmol})$. The mixture was refluxed under an inert atmosphere for $16 \mathrm{~h}$. The solution was cooled, the excess of un-reacted iron filtered, and evaporated. The crude product was re-dissolved in absolute EtOH $(30 \mathrm{~mL})$. An $\mathrm{H}_{2} \mathrm{SO}_{4}$ solution $(2 \mathrm{~mL}, 97 \%$ ) was carefully added and the solution was refluxed overnight. It was cooled and the solvents were rotor-evaporated. Distilled water $(100 \mathrm{~mL})$ was added and the $\mathrm{pH}$ was adjusted to 6 with an aqueous saturated solution of $\mathrm{NaHCO}_{3}$. Na 2 EDTA $(6.27 \mathrm{~g}, 16.8 \mathrm{mmol})$ was added to this solution followed by addition of $\mathrm{H}_{2} \mathrm{O}_{2}(1.5 \mathrm{~mL}, 30 \%)$ which resulted in the solution turning brown. The $\mathrm{pH}$ was then increased to 7 with an aqueous saturated solution of $\mathrm{NaHCO}_{3}$ before extraction with $\mathrm{CH}_{2} \mathrm{Cl}_{2}(5 \times 100 \mathrm{~mL})$. The organic phases were combined, dried over $\mathrm{Na}_{2} \mathrm{SO}_{4}$, filtered, and evaporated to dryness, resulting in a brown crude solid which was purified by column chromatography (silica gel; $\mathrm{CH}_{2} \mathrm{Cl}_{2} \rightarrow \mathrm{CH}_{2} \mathrm{Cl}_{2} / \mathrm{MeOH}$ 96:4) to give a pale yellow solid (532 mg, 79\% yield). ${ }^{1} \mathrm{H} \mathrm{NMR}(400 \mathrm{MHz}$, $298 \mathrm{~K}$, acetone- $\left.d_{6}\right) \delta(\mathrm{ppm}): 1.43\left(\mathrm{t},{ }^{3} \mathrm{~J}=6.8 \mathrm{~Hz}, 3 \mathrm{H}, \mathrm{OCH}_{2} \mathrm{CH}_{3}\right)$, $3.25\left(\mathrm{~s}, 6 \mathrm{H}, \mathrm{OCH}_{3}\right), 3.44\left(\mathrm{~m}, 4 \mathrm{H}, \mathrm{NCH}_{2} \mathrm{CH}_{2}\right), 3.50-3.54(\mathrm{~m}$, $\left.12 \mathrm{H}, \mathrm{OCH}_{2}\right), 3.59\left(\mathrm{~m}, 4 \mathrm{H}, \mathrm{OCH}_{2}\right), 3.66\left(\mathrm{~m}, 4 \mathrm{H}, \mathrm{OCH}_{2}\right), 4.29$ (s (broad), $\left.2 \mathrm{H}, \mathrm{CH}_{2}\right), 4.35$ (s, $\left.3 \mathrm{H}, \mathrm{NCH}_{3}\right), 4.43$ (s, 3H, $\mathrm{NCH}_{3}$ ), $4.44\left(\mathrm{q},{ }^{3} \mathrm{~J}=6.8 \mathrm{~Hz}, 2 \mathrm{H}, \mathrm{OCH}_{2} \mathrm{CH}_{3}\right), 7.32\left(\mathrm{dd},{ }^{3} \mathrm{~J}=8.5 \mathrm{~Hz},{ }^{4} \mathrm{~J}\right.$ $\left.=1.3 \mathrm{~Hz}, 1 \mathrm{H}, \mathrm{H}_{\text {Benz. }}\right), 7.34\left(\mathrm{dd},{ }^{3} J=8.5 \mathrm{~Hz},{ }^{4} J=1.3 \mathrm{~Hz}, 1 \mathrm{H}\right.$, $\mathrm{H}_{\text {Benz. }}$ ), 7.53 (d, $\left.{ }^{3} J=8.5 \mathrm{~Hz}, 1 \mathrm{H}, \mathrm{H}_{\text {Benz. }}\right), 7.55$ (d, ${ }^{3} J=8.5 \mathrm{~Hz}$, $1 \mathrm{H}, \mathrm{H}_{\text {Benz. }}$ ), 7.66 (d, $\left.{ }^{4} J=1.3 \mathrm{~Hz}, 1 \mathrm{H}, \mathrm{H}_{\text {Benz. }}\right), 7.68\left(\mathrm{~d},{ }^{4} J=\right.$ $\left.1.3 \mathrm{~Hz}, 1 \mathrm{H}, \mathrm{H}_{\text {Benz. }}\right), 8.15$ (d, $\left.{ }^{3} J=4.4 \mathrm{~Hz}, 2 \mathrm{H}, \mathrm{H}_{\text {Py. }}\right), 8.42\left(\mathrm{dd},{ }^{3} J\right.$ $\left.=8.5 \mathrm{~Hz},{ }^{4} \mathrm{~J}=2.4 \mathrm{~Hz}, 1 \mathrm{H}, \mathrm{H}_{\text {Py. }}\right), 8.59\left(\mathrm{~d},{ }^{3} \mathrm{~J}=8.5 \mathrm{~Hz}, 1 \mathrm{H}, \mathrm{H}_{\text {Py. }}\right)$, $8.62\left(\mathrm{t},{ }^{3} J=4.4 \mathrm{~Hz}, 1 \mathrm{H}, \mathrm{H}_{\mathrm{Py}}\right), 9.12\left(\mathrm{~d},{ }^{4} J=2.4 \mathrm{~Hz}, 1 \mathrm{H}, \mathrm{H}_{\text {Py. }}\right)$. ${ }^{13} \mathrm{C} \mathrm{NMR}\left(800 \mathrm{MHz}, 298 \mathrm{~K}, \mathrm{CDCl}_{3}\right) \delta(\mathrm{ppm}): 14.44\left(\mathrm{OCH}_{2} \mathrm{CH}_{3}\right)$, $33.11\left(\mathrm{NCH}_{3}\right), 33.27\left(\mathrm{NCH}_{3}\right), 42.34\left(\mathrm{CH}_{2}\right), 48.37\left(\mathrm{NCH}_{2} \mathrm{CH}_{2}\right)$, $59.18\left(\mathrm{OCH}_{3}\right), 62.01\left(\mathrm{OCH}_{2} \mathrm{CH}_{3}\right), 69.79\left(\mathrm{OCH}_{2}\right), 70.51$ $\left(\mathrm{OCH}_{2}\right), 70.62\left(\mathrm{OCH}_{2}\right), 70.65\left(\mathrm{OCH}_{2}\right), 72.01\left(\mathrm{OCH}_{2}\right), 110.19$ $\left(\mathrm{CH}_{\text {Benz. }}\right), 110.25\left(\mathrm{CH}_{\text {Benz. }}\right), 120.07\left(\mathrm{CH}_{\text {Benz. }}\right), 120.28\left(\mathrm{CH}_{\text {Benz. }}\right)$, 124.35 ( $\left.\mathrm{CH}_{\text {Benz. }}\right), 124.87$ ( $\left.\mathrm{CH}_{\mathrm{Py}}\right), 125.32\left(\mathrm{CH}_{\mathrm{Py}}\right), 125.85$ $\left(\mathrm{CH}_{\mathrm{Py}}\right), 127.48\left(\mathrm{CH}_{\mathrm{Py}}\right), 135.61\left(\mathrm{CH}_{\mathrm{Py}}\right), 136.09$ ( $\mathrm{C}_{\mathrm{Benz}}$ quat. $)$, 136.25 ( $\left.\mathrm{C}_{\text {Benz. quat. }}\right), 136.61$ ( $\left.\mathrm{C}_{\text {Benz. quat. }}\right), 137.04$ ( $\left.\mathrm{C}_{\text {Benz. quat. }}\right)$, 138.00 ( $\mathrm{CH}_{\mathrm{Py}}$ ), 143.00 ( $\mathrm{C}_{\text {Benz. quat. }}$ ), 147.17 (C $\left.\mathrm{C}_{\mathrm{Py} . \text { quat. }}\right), 147.21$ (C $\left.\mathrm{C}_{\text {Py. quat. }}\right), 148.63$ (С $\left.\mathrm{C}_{\text {Py. quat. }}\right), 149.27$ (C $\left.\mathrm{C}_{\text {Benz. quat. }}\right), 150.80$

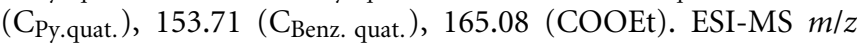
calcd for $\left[\mathrm{M}+\mathrm{H}^{+}\right]$(found): 874.38 (874.37); calcd for $[\mathrm{M}+$ $\left.2 \mathrm{H}^{+}\right] / 2$ (found): 437.83 (437.69).

\section{6-[5-(\{2-[5-(bis\{2-[2-(2-methoxyethoxy)ethoxy]ethyl\}sulfamoyl) pyridin-2-yl]-1-methyl-1H-benzimidazol-5-yl\}methyl)-1-methyl-1H- benzimidazol-2-yl]pyridine-2-carboxylic acid ( $\mathrm{HL}^{4}$ )}

Intermediate (12) (525 mg, $0.602 \mathrm{mmol})$ was dissolved in an absolute EtOH$/ \mathrm{H}_{2} \mathrm{O}$ mixture $(20: 20 \mathrm{~mL})$ containing $\mathrm{NaOH}$ (28.9 mg, $0.721 \mathrm{mmol})$. The mixture was stirred at $60^{\circ} \mathrm{C}$ for $16 \mathrm{~h}$. 
After completion of the reaction, the solvents were evaporated. The residue was dissolved in distilled water $(50 \mathrm{~mL})$ and the resulting aqueous solution was acidified to $\mathrm{pH}=2$ by addition of $0.02 \mathrm{M}$ hydrochloric acid. The acidic solution was then extracted with $\mathrm{CH}_{2} \mathrm{Cl}_{2}(5 \times 100 \mathrm{~mL})$, dried over $\mathrm{Na}_{2} \mathrm{SO}_{4}$ and evaporated. The crude product was triturated with hexane $(100 \mathrm{~mL})$, filtered, and dried under vacuum to give a pale yellow solid $(498 \mathrm{mg}$, $98 \%$ yield). ${ }^{1} \mathrm{H}$ NMR $\left(400 \mathrm{MHz}, 298 \mathrm{~K}\right.$, acetone- $\left.d_{6}\right) \delta(\mathrm{ppm})$ : $3.25\left(\mathrm{~s}, 6 \mathrm{H}, \mathrm{OCH}_{3}\right), 3.43\left(\mathrm{~m}, 4 \mathrm{H}, \mathrm{NCH}_{2} \mathrm{CH}_{2}\right), 3.50-3.54(\mathrm{~m}$, $\left.12 \mathrm{H}, \mathrm{OCH}_{2}\right), 3.59\left(\mathrm{~m}, 4 \mathrm{H}, \mathrm{OCH}_{2}\right), 3.66\left(\mathrm{~m}, 4 \mathrm{H}, \mathrm{OCH}_{2}\right), 4.30(\mathrm{~s}$ (broad), 2H, $\mathrm{CH}_{2}$ ), 4.35 (s, 3H, $\left.\mathrm{NCH}_{3}\right), 4.38\left(\mathrm{~s}, 3 \mathrm{H}, \mathrm{NCH}_{3}\right), 7.32$ (d, $\left.{ }^{3} J=8.1 \mathrm{~Hz}, 1 \mathrm{H}, \mathrm{H}_{\text {Benz. }}\right), 7.34$ (d, ${ }^{3} J=8.5 \mathrm{~Hz}, 1 \mathrm{H}, \mathrm{H}_{\text {Benz. }}$ ), $7.55\left(\mathrm{~d},{ }^{3} J=8.1 \mathrm{~Hz}, \mathrm{H}_{\text {Benz. }}\right), 7.55$ (d, $\left.{ }^{3} J=8.5 \mathrm{~Hz}, 1 \mathrm{H}, \mathrm{H}_{\text {Benz. }}\right)$, 7.68 (s, 1H, H Benz. $_{\text {) }} 7.68$ (s, $1 \mathrm{H}, \mathrm{H}_{\text {Benz. }}$ ), 8.20 (d, ${ }^{3} J=6.4 \mathrm{~Hz}, 1 \mathrm{H}$, $\left.\mathrm{H}_{\text {Py. }}\right), 8.21\left(\mathrm{~d},{ }^{3} \mathrm{~J}=4.7 \mathrm{~Hz}, 1 \mathrm{H}, \mathrm{H}_{\text {Py. }}\right), 8.41\left(\mathrm{dd},{ }^{3} J=8.5 \mathrm{~Hz},{ }^{4} J=\right.$ $\left.0.6 \mathrm{~Hz}, 1 \mathrm{H}, \mathrm{H}_{\text {Py. }}\right), 8.60\left(\mathrm{~d},{ }^{3} J=8.5 \mathrm{~Hz}, 1 \mathrm{H}, \mathrm{H}_{\text {Py. }}\right), 8.60\left(\mathrm{dd},{ }^{3} J=\right.$ $\left.6.4 \mathrm{~Hz},{ }^{3} \mathrm{~J}=4.7 \mathrm{~Hz}, 1 \mathrm{H}, \mathrm{H}_{\text {Py. }}\right), 9.12\left(\mathrm{~d},{ }^{4} \mathrm{~J}=0.6 \mathrm{~Hz}, 1 \mathrm{H}, \mathrm{H}_{\text {Py. }}\right) .{ }^{13} \mathrm{C}$ NMR $\left(800 \mathrm{MHz}, 298 \mathrm{~K}, \mathrm{CDCl}_{3}\right) \delta(\mathrm{ppm}): 32.62\left(\mathrm{NCH}_{3}\right), 33.31$ $\left(\mathrm{NCH}_{3}\right), 42.30\left(\mathrm{CH}_{2}\right), 48.38\left(\mathrm{NCH}_{2} \mathrm{CH}_{2}\right), 59.18\left(\mathrm{OCH}_{3}\right), 69.79$ $\left(\mathrm{OCH}_{2}\right), 70.50\left(\mathrm{OCH}_{2}\right), 70.62\left(\mathrm{OCH}_{2}\right), 70.64\left(\mathrm{OCH}_{2}\right), 72.01$ $\left(\mathrm{OCH}_{2}\right), 110.34\left(\mathrm{CH}_{\text {Benz. }}\right), 120.01$ ( $\left.\mathrm{CH}_{\text {Benz. }}\right), 120.17\left(\mathrm{CH}_{\text {Benz. }}\right)$, 124.36 ( $\left.\mathrm{CH}_{\text {Benz. }}\right), 124.42$ ( $\left.\mathrm{CH}_{\text {Benz. }}\right), 125.82\left(\mathrm{CH}_{\text {Py. }}\right), 125.86$ ( $\left.\mathrm{CH}_{\text {Py. }}\right), 128.64$ ( $\left.\mathrm{CH}_{\text {Py. }}\right), 135.51$ (C $\left.\mathrm{C}_{\text {Benz. quat. }}\right), 135.69$ ( $\mathrm{CH}_{\mathrm{Py}}$ ), 136.20 (С $\left.\mathrm{C}_{\text {Py. quat. }}\right), 136.95$ ( $\left.\mathrm{C}_{\text {Benz. quat. }}\right), 137.31$ ( $\mathrm{C}_{\text {Benz. quat. }}$ ), $139.24\left(\mathrm{CH}_{\mathrm{Py}}\right), 142.29$ ( $\left.\mathrm{C}_{\text {Benz. quat. }}\right), 142.82$ ( $\left.\mathrm{C}_{\text {Benz. quat. }}\right), 146.34$ ( $\left.\mathrm{C}_{\text {Py. quat. }}\right), 147.20\left(\mathrm{CH}_{\text {Py. }}\right), 148.66$ ( $\left.\mathrm{C}_{\text {Py. quat. }}\right), 148.71$ ( $\left.\mathrm{C}_{\text {Py. quat. }}\right)$,

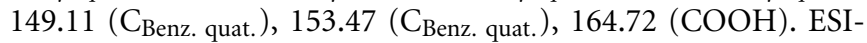
MS $m / z$ calc for $\left[\mathrm{M}+\mathrm{H}^{+}\right]$(found): 846.35 (846.21); calcd for $\left[\mathrm{M}+2 \mathrm{H}^{+}\right] / 2$ (found): 423.68 (423.75). Anal. Calcd for $\mathrm{C}_{42} \mathrm{H}_{51} \mathrm{~N}_{7} \mathrm{O}_{10} \mathrm{~S} \cdot \mathrm{H}_{2} \mathrm{O}$ (found): C, 58.43 (58.24); H, 6.18 (6.23); N, 11.36 (11.07).

\section{Ethyl 4-\{2-[2-(2-methoxyethoxy)ethoxy]ethoxy\}-6-(methyl\{4-[4- (methylamino)-3-nitrobenzyl]-2-nitrophenyl\}carbamoyl)pyridine-2- carboxylate (13)}

A mixture of 6-(ethoxycarbonyl)-4-\{2-[2-(2-methoxyethoxy) ethoxy] ethoxy]pyridine-2-carboxylic acid (9) (0.718 g, $2.01 \mathrm{mmol})$, freshly distilled $\mathrm{SOCl}_{2}(2.39 \mathrm{~g}, 20.0 \mathrm{mmol})$, and dry DMF $(77 \mu \mathrm{L}, 1.05 \mathrm{mmol})$ were refluxed in dry $\mathrm{CH}_{2} \mathrm{Cl}_{2}$ $(25 \mathrm{~mL})$ under an inert atmosphere for $2 \mathrm{~h}$. After evaporation and pumping for $2 \mathrm{~h}$, the pale yellow oil formed was re-dissolved in dry $\mathrm{CH}_{2} \mathrm{Cl}_{2}(25 \mathrm{~mL})$. 3,3'-dinitro-4,4'-bis $(N$ methylamino)diphenylmethane (8) (635 mg, $2.01 \mathrm{mmol})$ andNEt $_{3}(1.50 \mathrm{~mL})$ were then added. The resulting mixture was refluxed for $16 \mathrm{~h}$. and evaporated. The red-brown residue was re-dissolved in $\mathrm{CH}_{2} \mathrm{Cl}_{2}(100 \mathrm{~mL})$ and washed with half-saturated $\mathrm{NH}_{4} \mathrm{Cl}$ solution $(100 \mathrm{~mL})$. After separation, the aqueous phase was extracted with $\mathrm{CH}_{2} \mathrm{Cl}_{2}(2 \times 100 \mathrm{~mL})$. The combined organic phases were dried over $\mathrm{Na}_{2} \mathrm{SO}_{4}$ and evaporated. The resulting red-brown solid was purified by column chromatography (silica gel, $\mathrm{CH}_{2} \mathrm{Cl}_{2} \rightarrow \mathrm{CH}_{2} \mathrm{Cl}_{2} / \mathrm{MeOH}$ 97:3) to give the monosubstituted product (13) as orange-red oil ( $0.614 \mathrm{~g}, 47 \%$ yield). ${ }^{1} \mathrm{H}$ NMR $\left(400 \mathrm{MHz}, 433 \mathrm{~K}, \mathrm{DMSO}-d_{6}\right) \delta(\mathrm{ppm}): 1.27\left(\mathrm{t},{ }^{3} \mathrm{~J}=\right.$ $\left.7.2 \mathrm{~Hz}, 3 \mathrm{H}, \mathrm{OCH}_{2} \mathrm{CH}_{3}\right), 2.99\left(\mathrm{~d},{ }^{3} \mathrm{~J}=2.7 \mathrm{~Hz}, 3 \mathrm{H}, \mathrm{NHCH}_{3}\right)$, $3.27\left(\mathrm{~s}, 3 \mathrm{H}, \mathrm{OCH}_{3}\right), 3.38\left(\mathrm{~s}, 3 \mathrm{H}, \mathrm{NCH}_{3}\right), 3.45\left(\mathrm{~m}, 2 \mathrm{H}, \mathrm{OCH}_{2}\right)$, 3.54-3.57 (m, 4H, $\left.\mathrm{OCH}_{2}\right), 3.60\left(\mathrm{~m}, 2 \mathrm{H}, \mathrm{OCH}_{2}\right), 3.79(\mathrm{~m}, 2 \mathrm{H}$, $\left.\mathrm{OCH}_{2}\right), 3.99\left(\mathrm{~s}, 2 \mathrm{H}, \mathrm{CH}_{2}\right), 4.21\left(\mathrm{q},{ }^{3} \mathrm{~J}=7.2 \mathrm{~Hz}, 2 \mathrm{H}, \mathrm{OCH}_{2} \mathrm{CH}_{3}\right)$, $4.28\left(\mathrm{~m}, 2 \mathrm{H}, \mathrm{OCH}_{2}\right), 6.95\left(\mathrm{~d},{ }^{3} \mathrm{~J}=8.9 \mathrm{~Hz}, 1 \mathrm{H}, \mathrm{H}_{\text {Benz. }}\right), 7.36$ $\left(\mathrm{d},{ }^{4} J=1.0 \mathrm{~Hz}, 1 \mathrm{H}, \mathrm{H}_{\text {Py. }}\right), 7.37\left(\mathrm{~d},{ }^{3} J=8.9 \mathrm{~Hz}, 1 \mathrm{H}, \mathrm{H}_{\text {Benz. }}\right), 7.42$ $\left(\mathrm{d},{ }^{4} J=1.0 \mathrm{~Hz}, 1 \mathrm{H}, \mathrm{H}_{\mathrm{Py}}\right), 7.43\left(\mathrm{~d},{ }^{3} J=7.8 \mathrm{~Hz}, 1 \mathrm{H}, \mathrm{H}_{\text {Benz. }}\right), 7.51$ (d, ${ }^{3} J=7.8 \mathrm{~Hz}, 1 \mathrm{H}, \mathrm{H}_{\text {Benz. }}$ ), 7.77 (s (broad), $\left.1 \mathrm{H}, \mathrm{NH}\right), 7.85$ (s, $\left.1 \mathrm{H}, \mathrm{H}_{\text {Benz. }}\right), 7.92$ (s, $\left.1 \mathrm{H}, \mathrm{H}_{\text {Benz. }}\right) .{ }^{13} \mathrm{C} \mathrm{NMR}(800 \mathrm{MHz}, 327 \mathrm{~K}$, DMSO-d $\left.d_{6}\right) \delta$ (ppm): $13.33\left(\mathrm{OCH}_{2} \mathrm{CH}_{3}\right), 30.13\left(\mathrm{NHCH}_{3}\right), 38.17$ $\left(\mathrm{NCH}_{3}\right), 38.63\left(\mathrm{CH}_{2}\right), 58.50\left(\mathrm{OCH}_{3}\right), 61.47\left(\mathrm{OCH}_{2} \mathrm{CH}_{3}\right), 68.70$ $\left(\mathrm{OCH}_{2}\right), 68.94\left(\mathrm{OCH}_{2}\right), 70.11\left(\mathrm{OCH}_{2}\right), 70.30\left(\mathrm{OCH}_{2}\right), 70.52$ $\left(\mathrm{OCH}_{2}\right), 71.79\left(\mathrm{OCH}_{2}\right), 112.53\left(\mathrm{CH}_{\mathrm{Py}}\right), 113.40\left(\mathrm{CH}_{\mathrm{Py}}\right), 115.15$ ( $\left.\mathrm{CH}_{\text {Benz. }}\right), 125.54$ ( $\left.\mathrm{CH}_{\text {Benz. }}\right), 125.91$ ( $\left.\mathrm{CH}_{\text {Benz. }}\right), 127.05\left(\mathrm{CH}_{\text {Benz. }}\right)$, 131.28 ( $\left.\left.\mathrm{C}_{\text {Benz. quat. }}\right), 131.71 \mathrm{C}_{\text {Benz. quat. }}\right), 135.10$ ( $\left.\mathrm{CH}_{\text {Benz. }}\right)$, 136.53 (C $\left.\mathrm{C}_{\text {Benz. quat. }}\right), 137.73$ ( $\left.\mathrm{CH}_{\text {Benz. }}\right), 142.65$ ( $\left.\mathrm{C}_{\text {Benz. quat. }}\right)$,

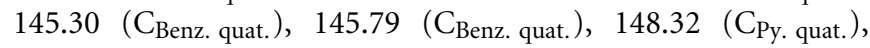
154.47 (C $\mathrm{C}_{\text {Py. quat. }}$ ), 164.24 (CONMe), 166.07 (COOEt), 166.43 (C $\mathrm{CPy}_{\mathrm{P}-\mathrm{O} \text { quat. }}$ ). ESI-MS $\mathrm{m} / \mathrm{z}$ calcd for $\left[\mathrm{M}+\mathrm{H}^{+}\right]$(found): 656.26 (656.06).

\section{Ethyl 6-[(4-\{4-[\{[5-(bis\{2-[2-(2-methoxyethoxy)ethoxy]ethyl\} sulfamoyl)pyridin-2-yl]-carbonyl\}(methyl)amino]-3-nitrobenzyl\}-2- nitrophenyl)(methyl)carbamoyl]-4-\{2-[2-(2-methoxyethoxy) ethoxy]ethoxy\}pyridine-2-carboxylate (14)}

A mixture of (6) $(1.12 \mathrm{~g}, 2.26 \mathrm{mmol})$, freshly distilled $\mathrm{SOCl}_{2}$ $(5.38 \mathrm{~g}, 45.2 \mathrm{mmol})$, and dry $\operatorname{DMF}(87 \mu \mathrm{L}, 1.13 \mathrm{mmol})$ were refluxed in dry $\mathrm{CH}_{2} \mathrm{Cl}_{2}(50 \mathrm{~mL})$ under an inert atmosphere for $2 \mathrm{~h}$. After evaporation and pumping for $2 \mathrm{~h}$, the brown oil formed was re-dissolved in dry $\mathrm{CH}_{2} \mathrm{Cl}_{2}(25 \mathrm{~mL})$ and $\mathrm{NEt}_{3}(2.00 \mathrm{~mL})$ was added. This mixture was refluxed and a solution of dry $\mathrm{CH}_{2} \mathrm{Cl}_{2}(25 \mathrm{~mL})$ containing (13) $(536 \mathrm{mg}, 8.17 \mathrm{mmol})$ was added dropwise over a period of $30 \mathrm{~min}$. The resulting solution was kept under reflux for $16 \mathrm{~h}$. and evaporated. The brown residue was re-dissolved in $\mathrm{CH}_{2} \mathrm{Cl}_{2}(100 \mathrm{~mL})$ and washed with half-saturated $\mathrm{NH}_{4} \mathrm{Cl}$ solution $(100 \mathrm{~mL})$. After separation, the aqueous phase was extracted with $\mathrm{CH}_{2} \mathrm{Cl}_{2}(2 \times 100 \mathrm{~mL})$. The combined organic phases were dried over $\mathrm{Na}_{2} \mathrm{SO}_{4}$ and evaporated. The crude material was purified by column chromatography (silica gel, $\mathrm{CH}_{2} \mathrm{Cl}_{2} / \mathrm{MeOH}$ 99:1 $\rightarrow \mathrm{CH}_{2} \mathrm{Cl}_{2} / \mathrm{MeOH}$ 95:5) to afford brown oil (725 mg, 79\% yield). ${ }^{1} \mathrm{H}$ NMR $\left(400 \mathrm{MHz}, 433 \mathrm{~K}, \mathrm{DMSO}-d_{6}\right) \delta$ (ppm): $1.28\left(\mathrm{t},{ }^{3} \mathrm{~J}=6.8 \mathrm{~Hz}, 3 \mathrm{H}, \mathrm{OCH}_{2} \mathrm{CH}_{3}\right), 3.27\left(\mathrm{~s}, 3 \mathrm{H}, \mathrm{OCH}_{3}\right)$, $3.28\left(\mathrm{~s}, 6 \mathrm{H}, \mathrm{OCH}_{3}\right), 3.39\left(\mathrm{~s}, 3 \mathrm{H}, \mathrm{NCH}_{3}\right), 3.40\left(\mathrm{~s}, 3 \mathrm{H}, \mathrm{NCH}_{3}\right)$, $3.40\left(\mathrm{~m}, 4 \mathrm{H}, \mathrm{NCH}_{2} \mathrm{CH}_{2}\right), 3.45-3.50\left(\mathrm{~m}, 14 \mathrm{H}, \mathrm{OCH}_{2}\right), 3.51-3.58$ $\left(\mathrm{m}, 12 \mathrm{H}, \mathrm{OCH}_{2}\right), 3.61\left(\mathrm{~m}, 2 \mathrm{H}, \mathrm{OCH}_{2}\right), 3.80\left(\mathrm{~m}, 2 \mathrm{H}, \mathrm{OCH}_{2}\right)$, 4.17 (s (broad), $\left.2 \mathrm{H}, \mathrm{CH}_{2}\right), 4.23\left(\mathrm{q},{ }^{3} \mathrm{~J}=6.8 \mathrm{~Hz}, 2 \mathrm{H}, \mathrm{OCH}_{2} \mathrm{CH}_{3}\right.$ ), $4.33\left(\mathrm{~m}, 2 \mathrm{H}, \mathrm{OCH}_{2}\right), 7.38\left(\mathrm{~d},{ }^{4} J=2.4 \mathrm{~Hz}, 1 \mathrm{H}, \mathrm{H}_{\mathrm{Py}}\right), 7.43(\mathrm{~d}$, $\left.{ }^{4} J=2.4 \mathrm{~Hz}, 2 \mathrm{H}, \mathrm{H}_{\mathrm{Py}}\right), 7.45-7.52\left(\mathrm{~d},{ }^{3} \mathrm{~J}=8.2 \mathrm{~Hz}, 3 \mathrm{H}, \mathrm{H}_{\text {Benz. }}\right)$, $7.80\left(\mathrm{~d},{ }^{3} \mathrm{~J}=8.2 \mathrm{~Hz}, 1 \mathrm{H}, \mathrm{H}_{\text {Py. }}\right), 7.86\left(\mathrm{~s}, 1 \mathrm{H}, \mathrm{H}_{\text {Benz. }}\right), 7.91(\mathrm{~s}, 1 \mathrm{H}$, $\left.\mathrm{H}_{\text {Benz. }}\right), 8.23\left(\mathrm{dd},{ }^{3} J=8.2 \mathrm{~Hz},{ }^{4} J=1.7 \mathrm{~Hz}, 1 \mathrm{H}, \mathrm{H}_{\text {Py. }}\right), 8.64(\mathrm{~s}, 1 \mathrm{H}$, $\left.\mathrm{H}_{\mathrm{Py}}\right) .{ }^{13} \mathrm{C} \mathrm{NMR}\left(800 \mathrm{MHz}, 327 \mathrm{~K}, \mathrm{DMSO}-d_{6}\right) \delta(\mathrm{ppm}): 13.66$ $\left(\mathrm{OCH}_{2} \mathrm{CH}_{3}\right), 37.45\left(\mathrm{NCH}_{3}\right), 38.27\left(\mathrm{NCH}_{3}\right), 47.23\left(\mathrm{NCH}_{2} \mathrm{CH}_{2}\right)$, $47.39\left(\mathrm{CH}_{2}\right), 57.81\left(\mathrm{OCH}_{3}\right), 60.79\left(\mathrm{OCH}_{2} \mathrm{CH}_{3}\right), 68.03\left(\mathrm{OCH}_{2}\right)$, $68.24\left(\mathrm{OCH}_{2}\right), 68.33\left(\mathrm{OCH}_{2}\right), 68.47\left(\mathrm{OCH}_{2}\right), 69.39\left(\mathrm{OCH}_{2}\right)$, $69.42\left(\mathrm{OCH}_{2}\right), 69.57\left(\mathrm{OCH}_{2}\right), 69.81\left(\mathrm{OCH}_{2}\right), 71.09\left(\mathrm{OCH}_{2}\right)$, 111.83 ( $\left.\mathrm{CH}_{\text {Py. }}\right), 112.76\left(\mathrm{CH}_{\text {Py. }}\right), 123.88\left(\mathrm{CH}_{\text {Benz. }}\right), 124.82$ ( $\left.\mathrm{CH}_{\text {Benz. }}\right), 125.18$ ( $\left.\mathrm{CH}_{\text {Py. }}\right), 131.12$ ( $\left.\mathrm{CH}_{\text {Benz. }}\right), 131.19\left(\mathrm{CH}_{\text {Benz. }}\right)$, 134.38 ( $\left.\mathrm{CH}_{\text {Benz. }}\right), 134.50$ ( $\left.\mathrm{CH}_{\text {Benz. }}\right), 135.20$ (C $\left.\mathrm{C}_{\text {Benz. quat. }}\right)$, 135.76 ( $\left.\mathrm{CH}_{\mathrm{Py}}\right), 136.21$ ( $\left.\mathrm{C}_{\text {Benz. quat. }}\right), 136.68\left(\mathrm{CH}_{\mathrm{Py}}\right), 140.50$ ( $\mathrm{C}_{\text {Benz. quat. }}$ ), 141.39 ( $\mathrm{C}_{\text {Benz. quat. }}$ ), 145.03 ( $\left.\mathrm{C}_{\text {Benz. quat. }}\right), 145.77$ ( $\left.\mathrm{C}_{\text {Py. quat. }}\right), 145.77$ ( $\left.\mathrm{C}_{\text {Benz. quat. }}\right), 147.62$ ( $\left.\mathrm{C}_{\text {Py. quat. }}\right), 153.67$ 


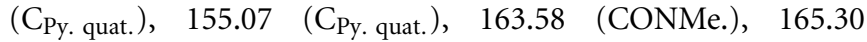
(CONMe), 165.78 (COOEt), 166.50 (CPy. -O quat.). ESI-MS $m / z$ calcd for $\left[\mathrm{M}+\mathrm{H}^{+}\right]$(found): 1132.44 (1132.28); calcd for $[\mathrm{M}+$ $\left.2 \mathrm{H}^{+}\right] / 2$ (found): 566.72 (566.76).

\section{Ethyl 6-[5-(\{2-[5-(bis\{2-[2-(2-methoxyethoxy)ethoxy]ethyl\}sulfamoyl) pyridin-2-yl]-1-methyl-1H-benzimidazol-5-yl\}methyl)-1-methyl-1H- benzimidazol-2-yl]-4-\{2-[2-(2-methoxyethoxy)ethoxy]ethoxy\} pyridine-2-carboxylate (15)}

Freshly activated iron powder $(1.07 \mathrm{~g}, 19.1 \mathrm{mmol})$ and $\mathrm{HCl}$ $(1.35 \mathrm{~mL}, 25 \%)$ were added to an $\mathrm{EtOH} / \mathrm{H}_{2} \mathrm{O}$ solution (125/31 mL) containing (15) (720 mg, $0.636 \mathrm{mmol})$. The mixture was refluxed under an inert atmosphere for $16 \mathrm{~h}$. The solution was cooled, the excess of un-reacted iron filtered, and evaporated. The crude product was re-dissolved in absolute EtOH $(30 \mathrm{~mL}) ; \mathrm{H}_{2} \mathrm{SO}_{4}(2 \mathrm{~mL}, 97 \%)$ was added carefully and the solution was refluxed overnight. It was cooled and the solvents were evaporated. Distilled water $(100 \mathrm{~mL})$ was added and the $\mathrm{pH}$ was adjusted to 6 with an aqueous saturated solution of $\mathrm{NaHCO}_{3} \cdot \mathrm{Na}_{2}$ EDTA $(4.74 \mathrm{~g}, 12.7 \mathrm{mmol})$ was added to this solution, followed by $\mathrm{H}_{2} \mathrm{O}_{2}(1.5 \mathrm{~mL}, 30 \%)$, which resulted in the solution turning brown. The $\mathrm{pH}$ was then increased to 7 with a saturated solution of aqueous $\mathrm{NaHCO}_{3}$ before extraction with $\mathrm{CH}_{2} \mathrm{Cl}_{2}(5 \times 100 \mathrm{~mL})$. The organic phases were combined, dried over $\mathrm{Na}_{2} \mathrm{SO}_{4}$, filtered, and evaporated to dryness, resulting in a brown crude solid which was purified by column chromatography (silica gel; $\mathrm{CH}_{2} \mathrm{Cl}_{2} \rightarrow \mathrm{CH}_{2} \mathrm{Cl}_{2} / \mathrm{MeOH}$ 95:5) to give a pale yellow solid ( $585 \mathrm{mg}, 89 \%$ yield). ${ }^{1} \mathrm{H} \mathrm{NMR}$ $\left(400 \mathrm{MHz}, 298 \mathrm{~K}\right.$, acetone- $\left.d_{6}\right) \delta(\mathrm{ppm}): 1.42\left(\mathrm{t},{ }^{3} \mathrm{~J}=7.2 \mathrm{~Hz}\right.$, $\left.3 \mathrm{H}, \mathrm{OCH}_{2} \mathrm{CH}_{3}\right), 3.25\left(\mathrm{~s}, 3 \mathrm{H}, \mathrm{OCH}_{3}\right), 3.26\left(\mathrm{~s}, 6 \mathrm{H}, \mathrm{OCH}_{3}\right)$, $3.43\left(\mathrm{~m}, 4 \mathrm{H}, \mathrm{NCH}_{2} \mathrm{CH}_{2}\right), 3.44\left(\mathrm{~m}, 2 \mathrm{H}, \mathrm{OCH}_{2}\right), 3.50-3.55$ $\left(\mathrm{m}, 12 \mathrm{H}, \mathrm{OCH}_{2}\right), 3.56-3.62\left(\mathrm{~m}, 8 \mathrm{H}, \mathrm{OCH}_{2}\right), 3.65-3.70(\mathrm{~m}$, $\left.6 \mathrm{H}, \mathrm{OCH}_{2}\right), 3.93\left(\mathrm{~m}, 2 \mathrm{H}, \mathrm{OCH}_{2}\right), 4.29$ (s (broad), $2 \mathrm{H}, \mathrm{CH}_{2}$ ), $4.35\left(\mathrm{~s}, 3 \mathrm{H}, \mathrm{NCH}_{3}\right), 4.41\left(\mathrm{~s}, 3 \mathrm{H}, \mathrm{NCH}_{3}\right), 4.42\left(\mathrm{q},{ }^{3} \mathrm{~J}=6.8 \mathrm{~Hz}\right.$, $\left.2 \mathrm{H}, \mathrm{OCH}_{2} \mathrm{CH}_{3}\right), 4.45\left(\mathrm{~m}, 2 \mathrm{H}, \mathrm{OCH}_{2}\right), 7.31\left(\mathrm{dd},{ }^{3} \mathrm{~J}=8.5 \mathrm{~Hz}\right.$, $\left.{ }^{4} J=1.4 \mathrm{~Hz}, 1 \mathrm{H}, \mathrm{H}_{\text {Benz. }}\right), 7.35\left(\mathrm{dd},{ }^{3} \mathrm{~J}=8.8 \mathrm{~Hz},{ }^{4} \mathrm{~J}=1.4 \mathrm{~Hz}\right.$, $\left.1 \mathrm{H}, \mathrm{H}_{\text {Benz. }}\right), 7.53$ (d, $\left.,^{3} \mathrm{~J}=8.5 \mathrm{~Hz}, 1 \mathrm{H}, \mathrm{H}_{\text {Benz. }}\right), 7.55$ (d, ${ }^{3} \mathrm{~J}=$ $\left.8.8 \mathrm{~Hz}, 1 \mathrm{H}, \mathrm{H}_{\text {Benz. }}\right), 7.65\left(\mathrm{~d},{ }^{4} \mathrm{~J}=1.4 \mathrm{~Hz}, 1 \mathrm{H}, \mathrm{H}_{\text {Benz. }}\right), 7.68$ $\left(\mathrm{d},{ }^{4} J=1.4 \mathrm{~Hz}, 1 \mathrm{H}, \mathrm{H}_{\text {Benz. }}\right), 7.68\left(\mathrm{~d},{ }^{4} J=2.4 \mathrm{~Hz}, 1 \mathrm{H}, \mathrm{H}_{\mathrm{Py}}\right)$, $8.14\left(\mathrm{~d},{ }^{4} \mathrm{~J}=2.4 \mathrm{~Hz}, 1 \mathrm{H}, \mathrm{H}_{\mathrm{Py}}\right), 8.40\left(\mathrm{dd},{ }^{3} \mathrm{~J}=8.5 \mathrm{~Hz},{ }^{4} \mathrm{~J}=\right.$ $\left.2.4 \mathrm{~Hz}, 1 \mathrm{H}, \mathrm{H}_{\mathrm{Py}}\right), 8.60\left(\mathrm{~d},{ }^{3} \mathrm{~J}=8.5 \mathrm{~Hz}, 1 \mathrm{H}, \mathrm{H}_{\mathrm{Py}}\right), 9.12(\mathrm{~d}$, $\left.{ }^{4} J=2.4 \mathrm{~Hz}, 1 \mathrm{H}, \mathrm{H}_{\mathrm{Py}}\right) .{ }^{13} \mathrm{C} \mathrm{NMR}\left(800 \mathrm{MHz}, 298 \mathrm{~K}, \mathrm{CDCl}_{3}\right)$ $\delta(\mathrm{ppm}): 14.42\left(\mathrm{OCH}_{2} \underline{\mathrm{CH}}_{3}\right), 33.12\left(\mathrm{NCH}_{3}\right), 33.26\left(\mathrm{NCH}_{3}\right)$, $42.36\left(\mathrm{CH}_{2}\right), 48.37\left(\mathrm{NCH}_{2} \mathrm{CH}_{2}\right), 59.18\left(\mathrm{OCH}_{3}\right), 59.21\left(\mathrm{OCH}_{3}\right)$, $62.01\left(\mathrm{OCH}_{2} \mathrm{CH}_{3}\right), 68.34\left(\mathrm{OCH}_{2}\right), 69.35\left(\mathrm{OCH}_{2}\right), 69.80$ $\left(\mathrm{OCH}_{2}\right), 70.51\left(\mathrm{OCH}_{2}\right), 70.62\left(\mathrm{OCH}_{2}\right), 70.65\left(\mathrm{OCH}_{2}\right), 70.75$ $\left(\mathrm{OCH}_{2}\right), 70.79\left(\mathrm{OCH}_{2}\right), 71.09\left(\mathrm{OCH}_{2}\right), 72.02\left(\mathrm{OCH}_{2}\right), 70.05$ $\left(\mathrm{OCH}_{2}\right), 110.19\left(\mathrm{CH}_{\text {Benz. }}\right), 110.23\left(\mathrm{CH}_{\text {Benz. }}\right), 111.93\left(\mathrm{CH}_{\mathrm{Py}}\right)$, $113.53\left(\mathrm{CH}_{\mathrm{Py}}\right) 120.01$ ( $\left.\mathrm{CH}_{\text {Benz. }}\right), 120.29$ ( $\left.\mathrm{CH}_{\text {Benz. }}\right), 124.34$ $\left(\mathrm{CH}_{\text {Benz. }}\right), 125.22$ ( $\left.\mathrm{CH}_{\text {Py. }}\right), 125.85$ ( $\left.\mathrm{CH}_{\mathrm{Py} .}\right), 135.61\left(\mathrm{CH}_{\mathrm{Py}}\right)$, 136.08 ( $\left.\mathrm{C}_{\text {Benz. quat. }}\right), 136.25$ ( $\left.\mathrm{C}_{\text {Benz. quat. }}\right), 136.53$ ( $\mathrm{C}_{\text {Benz. quat. }}$ ),

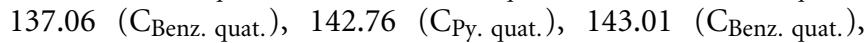
147.17 ( $\left.\mathrm{C}_{\text {Py. quat. }}\right), 148.64$ ( $\left.\mathrm{C}_{\text {Py. quat. }}\right), 148.75$ (Сy. quat. $), 149.49$ ( $\left.\mathrm{C}_{\text {Benz. quat. }}\right), 152.42$ ( $\left.\mathrm{C}_{\text {Benz. quat. }}\right), 153.71$ ( $\left.\mathrm{C}_{\text {Benz. quat. }}\right), 165.05$ (COOEt), 166.50 (C $\mathrm{C}_{\text {Py.-Oquat. }}$ ). ESI-MS $m / z$ calcd for $\left[\mathrm{M}+\mathrm{H}^{+}\right]$ (found): 1036.47 (1036.25); calcd for $\left[\mathrm{M}+2 \mathrm{H}^{+}\right] / 2$ (found): 518.74 (518.86).

\section{6-[5-(\{2-[5-(bis\{2-[2-(2-methoxyethoxy)ethoxy]ethyl\}sulfamoyl) pyridin-2-yl]-1-methyl-1H-benzimidazol-5-yl\}methyl)-1-methyl-1H- benzimidazol-2-yl]-4-\{2-[2-(2-methoxyethoxy)ethoxy]ethoxy\} pyridine-2-carboxylic acid $\left(\mathrm{HL}^{5}\right)$}

Intermediate $(\mathbf{1 6})\left(575 \mathrm{mg}, 5.56 \times 10^{-1} \mathrm{mmol}\right)$ was dissolved in an absolute $\mathrm{EtOH} / \mathrm{H}_{2} \mathrm{O}$ solution $(20 / 5 \mathrm{~mL})$ containing $\mathrm{NaOH}$ $(26.7 \mathrm{mg}, 0.667 \mathrm{mmol})$. This mixture was stirred at $60^{\circ} \mathrm{C}$ for $16 \mathrm{~h}$. After completion of the reaction, the solvents were evaporated. The residue was dissolved in distilled water $(50 \mathrm{~mL})$ and the resulting aqueous solution was acidified to $\mathrm{pH}=2$ by addition of $0.02 \mathrm{M}$ hydrochloric acid. The acidic solution was then extracted with $\mathrm{CH}_{2} \mathrm{Cl}_{2}(5 \times 100 \mathrm{~mL})$, dried over $\mathrm{Na}_{2} \mathrm{SO}_{4}$, and evaporated. The crude product was triturated with hexane $(100 \mathrm{~mL})$, filtered and dried under vacuum to give a pale yellow solid $(560 \mathrm{mg}$, $100 \%$ yield). ${ }^{1} \mathrm{H}$ NMR $\left(400 \mathrm{MHz}, 298 \mathrm{~K}\right.$, acetone- $\left.d_{6}\right) \delta(\mathrm{ppm})$ : $3.25\left(\mathrm{~s}, 9 \mathrm{H}, \mathrm{OCH}_{3}\right), 3.43\left(\mathrm{~m}, 4 \mathrm{H}, \mathrm{NCH}_{2} \mathrm{CH}_{2}\right), 3.45(\mathrm{~m}, 2 \mathrm{H}$, $\left.\mathrm{OCH}_{2}\right), 3.50-3.54\left(\mathrm{~m}, 12 \mathrm{H}, \mathrm{OCH}_{2}\right), 3.55-3.62\left(\mathrm{~m}, 8 \mathrm{H}, \mathrm{OCH}_{2}\right)$, 3.65-3.70 (m, 6H, $\left.\mathrm{OCH}_{2}\right), 3.93\left(\mathrm{~m}, 2 \mathrm{H}, \mathrm{OCH}_{2}\right), 4.29$ (s (broad), $\left.2 \mathrm{H}, \mathrm{CH}_{2}\right), 4.33\left(\mathrm{~s}, 3 \mathrm{H}, \mathrm{NCH}_{3}\right), 4.35\left(\mathrm{~s}, 3 \mathrm{H}, \mathrm{NCH}_{3}\right), 4.47(\mathrm{~m}$, $\left.2 \mathrm{H}, \mathrm{OCH}_{2}\right), 7.31\left(\mathrm{dd},{ }^{3} \mathrm{~J}=8.5 \mathrm{~Hz},{ }^{4} \mathrm{~J}=1.4 \mathrm{~Hz}, 1 \mathrm{H}, \mathrm{H}_{\text {Benz. }}\right)$, $7.34\left(\mathrm{dd},{ }^{3} \mathrm{~J}=8.5 \mathrm{~Hz},{ }^{4} \mathrm{~J}=1.4 \mathrm{~Hz}, 1 \mathrm{H}, \mathrm{H}_{\text {Benz. }}\right), 7.53\left(\mathrm{~d},{ }^{3} \mathrm{~J}=\right.$ $\left.8.5 \mathrm{~Hz}, 1 \mathrm{H}, \mathrm{H}_{\text {Benz. }}\right), 7.55$ (d, $\left.{ }^{3} J=8.5 \mathrm{~Hz}, 1 \mathrm{H}, \mathrm{H}_{\text {Benz. }}\right), 7.65$ (d, $\left.{ }^{4} J=1.4 \mathrm{~Hz}, 1 \mathrm{H}, \mathrm{H}_{\text {Benz. }}\right), 7.68\left(\mathrm{~d},{ }^{4} J=1.4 \mathrm{~Hz}, 1 \mathrm{H}, \mathrm{H}_{\text {Benz. }}\right), 7.68$ $\left(\mathrm{d},{ }^{4} J=2.4 \mathrm{~Hz}, 1 \mathrm{H}, \mathrm{H}_{\mathrm{Py}}\right), 8.14\left(\mathrm{~d},{ }^{4} J=2.4 \mathrm{~Hz}, 1 \mathrm{H}, \mathrm{H}_{\text {Py. }}\right), 8.40$ $\left(\mathrm{dd},{ }^{3} J=8.2 \mathrm{~Hz},{ }^{4} J=2.4 \mathrm{~Hz}, 1 \mathrm{H}, \mathrm{H}_{\mathrm{Py}}\right), 8.60\left(\mathrm{~d},{ }^{3} J=8.2 \mathrm{~Hz}\right.$, $\left.1 \mathrm{H}, \mathrm{H}_{\text {Py. }}\right), 9.12\left(\mathrm{~d},{ }^{4} \mathrm{~J}=2.4 \mathrm{~Hz}, 1 \mathrm{H}, \mathrm{H}_{\mathrm{Py}}\right) .{ }^{13} \mathrm{C} \mathrm{NMR}(800 \mathrm{MHz}$, $\left.298 \mathrm{~K}, \mathrm{CDCl}_{3}\right) \delta(\mathrm{ppm}): 32.80\left(\mathrm{NCH}_{3}\right), 33.29\left(\mathrm{NCH}_{3}\right), 42.33$ $\left(\mathrm{CH}_{2}\right), 48.39\left(\mathrm{NCH}_{2} \mathrm{CH}_{2}\right), 59.18\left(\mathrm{OCH}_{3}\right), 59.20\left(\mathrm{OCH}_{3}\right), 68.67$ $\left(\mathrm{OCH}_{2}\right), 69.24\left(\mathrm{OCH}_{2}\right), 69.80\left(\mathrm{OCH}_{2}\right), 70.51\left(\mathrm{OCH}_{2}\right), 70.62$ $\left(\mathrm{OCH}_{2}\right), 70.65\left(\mathrm{OCH}_{2}\right), 70.74\left(\mathrm{OCH}_{2}\right), 70.78\left(\mathrm{OCH}_{2}\right), 71.11$ $\left(\mathrm{OCH}_{2}\right), 72.02\left(\mathrm{OCH}_{2}\right), 72.03\left(\mathrm{OCH}_{2}\right), 110.27\left(\mathrm{CH}_{\text {Benz. }}\right), 110.31$ $\left(\mathrm{CH}_{\text {Benz. }}\right), 111.38\left(\mathrm{CH}_{\text {Py. }}\right), 113.85\left(\mathrm{CH}_{\text {Py. }}\right), 120.02\left(\mathrm{CH}_{\text {Benz. }}\right)$, $120.23\left(\mathrm{CH}_{\text {Benz. }}\right), 124.35\left(\mathrm{CH}_{\text {Benz. }}\right), 125.58\left(\mathrm{CH}_{\mathrm{Py}}\right), 125.86$ $\left(\mathrm{CH}_{\mathrm{Py}}\right.$ ) $), 135.64$ ( $\left.\mathrm{C}_{\text {Benz. quat. }}\right), 135.71\left(\mathrm{CH}_{\mathrm{Py}}\right), 136.12$ (C $\left.\mathrm{C}_{\text {Py. quat. }}\right)$, 136.25 ( $\mathrm{CH}_{\mathrm{Py}}$.), 136.98 ( $\left.\mathrm{C}_{\text {Benz. quat. }}\right), 139.42$ ( $\left.\mathrm{C}_{\text {Benz. quat. }}\right), 142.44$ ( $\left.\mathrm{C}_{\text {Benz. quat. }}\right), 142.95$ ( $\left.\mathrm{C}_{\text {Benz. quat. }}\right), 147.18$ (Сy. quat. $), 148.68$ (C $\left.\mathrm{C}_{\text {Py. quat. }}\right), 149.12$ ( $\left.\mathrm{C}_{\text {Benz. quat. }}\right), 150.54$ (C $\left.\mathrm{C}_{\text {Py. quat. }}\right), 153.62$ ( $\left.\mathrm{C}_{\text {Benz. quat. }}\right), 164.90$ (COOH), 167.29 ( $\left.\mathrm{C}_{\mathrm{Py}-\text { Oquat. }}\right)$. ESI-MS $\mathrm{m} / \mathrm{z}$ calcd for $\left[\mathrm{M}+\mathrm{H}^{+}\right]$(found): 1008.44 (1008.29); calcd for $\left[\mathrm{M}+2 \mathrm{H}^{+}\right] / 2$ (found): 504.72 (504.87). Anal. Calcd for $\mathrm{C}_{49} \mathrm{H}_{65} \mathrm{~N}_{7} \mathrm{O}_{14} \mathrm{~S} \cdot \mathrm{H}_{2} \mathrm{O}$ (found): C, 57.39 (57.14); H, 6.58 (6.65); N, 9.56 (9.29).

\section{ANALYTICAL AND SPECTROSCOPIC MEASUREMENTS}

Elemental analyses were performed by Dr. E. Solari, Elementary Analysis Laboratory of the Institute of Chemical Sciences and Engineering, EPFL. NMR spectra were measured on Bruker Avance DRX $400\left({ }^{1} \mathrm{H}, 400 \mathrm{MHz}\right)$, AV $600\left({ }^{13} \mathrm{C}, 150.864 \mathrm{MHz}\right)$, and AV $800\left({ }^{13} \mathrm{C}, 201.54 \mathrm{MHz}\right)$ spectrometers. Spectra of organic compounds were recorded in $\mathrm{CDCl}_{3}(99.8 \%), \mathrm{CD}_{3} \mathrm{CN}$ (99.8\%), acetone- $d_{6}(99.5 \%), \mathrm{DMSO}-d_{6}(99.8 \%)$, and $\mathrm{D}_{2} \mathrm{O}(99.9 \%)$, all from Aldrich Chemicals. Deuterated solvents were taken as internal standards; chemical shift values are given in ppm with respect to TMS and $J$ values are reported in Hz. The ESIMS spectra of the organic compounds were obtained on a Finningan TSQ 7100 spectrometer using $10^{-5}-10^{-4} \mathrm{M}$ solutions in acetonitrile/ $\mathrm{H}_{2} \mathrm{O} /$ formic acid $(49.5 / 49.5 / 1)$ or $\mathrm{MeOH}$; 
the capillary temperature was set to $180^{\circ} \mathrm{C}$ and the ion spray voltage to $3.5 \mathrm{kV}$. The instrument was calibrated using horse myoglobin and the analyses were conducted in positive mode. Phosphoric acid was used for mass calibration in the range 500$2000 \mathrm{~m} / z$. Data were acquired and processed with Masslynx version 4.0. Electrospray conditions were as follows: capillary voltage, $3 \mathrm{kV}$; source temperature, $80^{\circ} \mathrm{C}$; cone voltage, $35 \mathrm{~V}$; source block temperature, $150^{\circ} \mathrm{C}$. The ESI nebulization and drying gas was nitrogen. The sample was introduced through a syringe pump operating at $20 \mu \mathrm{L} \cdot \mathrm{min}^{-1}$. Simulation of spectra was achieved with Molecular Weight Calculator $6.42^{\circledR}$. UV/Vis absorption spectra were measured in $1.0 \mathrm{~cm}$ quartz Suprasil ${ }^{\circledR}$ cells on a Perkin-Elmer Lambda 900 spectrometer. Stability constants were determined by spectrophotometric titration of $\left(\mathrm{L}^{4,5}\right)^{-}$by $\mathrm{Eu}^{\mathrm{III}}$ or $\mathrm{Eu}^{\mathrm{III}} / \mathrm{Zn}^{\mathrm{II}}(1: 1)$ in Tris- $\mathrm{HCl} 0.1 \mathrm{M}(\mathrm{pH} 7.4)$ under $\mathrm{N}_{2}$ atmosphere. All titrations were performed batch wise in thermostated $\left(25.0 \pm 0.1^{\circ} \mathrm{C}\right) 1-\mathrm{cm}$ quartz cuvettes. Factor analysis (Malinowski and Howery, 1991) and mathematical treatment of the spectrophotometric data were performed with the Specfit ${ }^{\circledR}$ software (Gampp et al., 1986). Luminescence spectra and lifetimes were collected either on a Horiba-Jobin Yvon FL 3-22 fluorometer or on a home-made high-resolution set-up, according to procedures published previously (Rodriguez-Cortinas et al., 2002). Quantum yields were measured by an absolute method using a specially designed integration sphere (Aebischer et al., 2009).

\section{ACKNOWLEDGMENTS}

This project was funded by the Swiss National Science Foundation (grant 200020_119866/1). Jean-Claude G. Bünzli thanks the

\section{REFERENCES}

Aebischer, A., Gumy, F., and Bünzli, J.-C. G. (2009). Intrinsic quantum yields and radiative lifetimes of lanthanide tris(dipicolinates). Phys. Chem. Chem. Phys. 11, 1346-1353. doi: $10.1039 / \mathrm{b} 816131 \mathrm{c}$

André, N., Jensen, T. B., Scopelliti, R., Imbert, D., Elhabiri, M., Hopfgartner, G., et al. (2004). Supramolecular recognition of heteropairs of lanthanide ions: a step toward self-assembled bifunctional probes. Inorg. Chem. 43, 515-529. doi: $10.1021 /$ ic0351996

Bernardinelli, G., Piguet, C., and Williams, A. F. (1992). The 1st self-assembled dinuclear triplehelical lanthanide complex synthesis and structure. Angew. Chem. Int. Ed. 31, 1622-1624. doi: 10.1002/anie.199216221

Bünzli, J.-C. G., Chauvin, A.-S., Vandevyver, C. D. B., Song, B., and Comby, S. (2008). Lanthanide bimetallic helicates for in vitro imaging and sensing. Ann. N.Y. Acad. Sci. 1130, 97-105. doi: 10.1196/annals. 1430.010

Bünzli, J.-C. G., and Mabillard, C. (1986). FT IR investigation of the interaction between perchlorate and trivalent neodymium, europium, terbium, and erbium ions in anhydrous acetonitrile. Inorg. Chem. 25, 2750-2754. doi: 10.1021/ic00236a020

Canard, G., and Piguet, C. (2007). The origin of the surprising stabilities of highly charged self-assembled polymetallic complexes in solution. Inorg. Chem. 46, 3511-3522. doi: 10.1021/ic062126o

Chauvin, A.-S., Comby, S., Song, B., Vandevyver, C. D. B., and Bünzli, J.-C. G. (2008). A versatile ditopic ligand system for sensitizing the luminescence of bimetallic lanthanide bio-imaging probes. 10.1002/chem.200701357

Chauvin, A.-S., Thomas, F., Song, B., Vandevyver, C. D. B., and Bünzli, J.-C. G. (2013). Synthesis and cell localization of self-assembled dinuclear lanthanide bioprobes. Philos. Trans. A Math. Phys. Eng. rsta.2012.0295

Comby, S., Stomeo, F., McCoy, C. P., and Gunnlaugsson, T. (2009). Formation of novel Chem. Eur. J. 14, 1726-1739. doi: Sci. 371:20120295. doi: 10.1098/

WCU program from the National Science Foundation of Korea (grant R31-2012-000-10035-0) for support.

\section{SUPPLEMENTARY MATERIAL}

The Supplementary Material for this article can be found online at: http://www.frontiersin.org/Inorganic_Chemistry/10.3389/ fchem.2013.00015/abstract

Figure S1 | (Top) Re-calculated spectra from the titration of $\mathrm{HL}^{6}$ with zinc perchlorate at $295 \mathrm{~K}$ and $\mathrm{pH}$ 7.4. (Bottom) Absorbance values extracted at different wavelengths during the titration compared with theoretical prediction from the stability extracted from the fit procedure (Table 1).

Figure S2 | (Top) Re-calculated spectra from the titration of $\mathrm{HL}^{6}$ with europium perchlorate at $295 \mathrm{~K}$ and pH 7.4. (Bottom) Absorbance values extracted at different wavelengths during the titration compared with theoretical prediction from the stability extracted from the fit procedure (Table 1).

Figure S3 | (Top) Re-calculated spectra from the titration of $\mathrm{HL}^{6}$ with zinc and europium perchlorate (1:1) at $295 \mathrm{~K}$ and $\mathrm{pH}$ 7.4. (Bottom) Absorbance values extracted at different wavelengths during the titration compared with theoretical prediction from the stability extracted from the fit procedure (Table 1).

Figure S4 | Effect on luminescence spectra of the addition of $\mathrm{Zn}$ " to a stoichiometric 1:3 Eu ${ }^{\prime \prime \prime}:\left(L^{6}\right)^{-}$solution $16.4 \mu \mathrm{M}$ in ligand, $\mathrm{pH}$ 7.4.

Figure S5 | Stoichiometric solution 1:3 Eu'I': $\left(\mathrm{L}^{6}\right)^{-}$(left) and 1:1:3 $\mathrm{Eu}^{\mathrm{III}}: \mathrm{Zn}^{\mathrm{II}}:\left(\mathrm{L}^{6}\right)^{-}$under irradiation at $366 \mathrm{~nm}$; total ligand concentration: 16.4 $\mu \mathrm{M}$ in ligand, $\mathrm{pH}$ 7.4.

Figure S6 | Emission spectra of solutions in Tris- $\mathrm{HCl} 0.1 \mathrm{M}(\mathrm{pH}$ 7.4) with different stoichiometries; $\lambda_{\text {exc }}=3.7 \mathrm{~nm} ;\left[\left(\mathrm{L}^{6}\right)^{-}\right]_{\mathrm{t}}=16.2 \mu \mathrm{M}$; the star denotes an artifact (2nd order Rayleigh band from excitation beam).

dinuclear lanthanide luminescent samarium(III), europium(III), and terbium(III) triple-stranded helicates from a C-2-Symmetrical Pyridine-2,6-dicarboxamide-Based 1,3-Xylenediyl-linked ligand in MeCN. Helv. Chim. Acta 92, 2461-2473. doi: 10.1002/hlca.2009 00213

Deiters, E., Song, B., Chauvin, A.-S., Vandevyver, C., and Bünzli, J.-C. G. (2009). Luminescent bimetallic lanthanide bioprobes for cellular imaging with excitation into the visible. Chem. Eur. J. 15, 885-900. doi: $10.1002 /$ chem. 200801868

Delarge, J. (1965). Sulfonation des picolines et oxydation des acides picolinesulfoniques. Il Farm. Ed. Sci. 20, 629-633.

Edder, C., Piguet, C., Bernardinelli, G., Mareda, J., Bochet, C. G., and Bünzli, J.-C. G., et al. (2000). Unusual electronic effects of electro-withdrawing sulfonamide groups in optically and magnetically active self-assembled non-covalent heterodimetallic d-f- podates. Inorg. Chem. 39, 5059-5073. doi: $10.1021 / \mathrm{ic} 000687 \mathrm{o}$
Edder, C., Piguet, C., Bünzli, J.-C. G., and Hopfgartner, G. (1997). A water-soluble and strongly luminescent self-assembled non-covalent lanthanide podate. J. Chem. Soc. Dalton Trans. 1997, 4657-4663. doi: 10.1039/a706256g

Edder, C., Piguet, C., Bünzli, J.-C. G., and Hopfgartner, G. (2001). High spin iron(II) as inner filter for $\mathrm{Eu}(\mathrm{III})$ luminescence in heterodimetallic d-f complexes. Chem. Eur. J. 7, 3014-3024.

Elhabiri, M., Hamacek, J., Bünzli, J.-C. G., and Albrecht-Gary, A.-M. (2004). Lanthanide homodimetallic triple-stranded helicates: insight into the self-assembly mechanism. Eur. J. Inorg. Chem. 2004, 51-62. doi: 10.1002/ejic.200300549

Elhabiri, M., Scopelliti, R., Bünzli, J.-C. G., and Piguet, C. (1998). The first lanthanide-containing helicates self-assembled in water. Chem. Commun. 1998, 2347-2349. doi: $10.1039 / \mathrm{a} 806730 \mathrm{i}$

Elhabiri, M., Scopelliti, R., Bünzli, J.-C. G., and Piguet, C. (1999). Lanthanide helicates self-assembled in water: a new class of highly 
stable and luminescent dimetallic carboxylates. J. Am. Chem. Soc. 121, 10747-10762. doi: 10.1021/ ja991854q

Fernandez-Moreira, V., Song, B., Sivagnanam, V., Chauvin, A.-S., Vandevyver, C. D. B., Gijs, M. A. M., et al. (2010). Bioconjugated lanthanide luminescent helicates as multilabels for lab-on-a-chip detection of cancer biomarkers. Analyst 135, 42-52. doi: 10.1039/b922124g

Gampp, H., Maeder, M., Meyer, C. J., and Zuberbühler, A. D. (1986). Calculation of equilibrium constants from multiwavelength spectroscopic data - iv. model-free least-squares refinement by use of evolving factor analysis. Talanta 33, 943-951. doi: 10.1016/00399140(86)80233-8

Gonçalves e Silva, F. R., Malta, O. L., Reinhard, C., Güdel, H. U., Piguet, C., Moser, J. E., et al. (2002). visible and near-infrared luminescence of lanthanide-containing dimetallic triple-stranded helicates: energy transfer mechanisms in the Sm(III) and $\mathrm{Yb}(\mathrm{III})$ molecular edifices. J. Phys. Chem. A 106, 1670-1677. doi: 10.1021/jp012884u

Hamacek, J., Blanc, S., Elhabiri, M., Leize, E., van Dorsselaer, A., Piguet, C., et al. (2003). Selfassembly mechanism of a bimetallic europium triple-stranded helicate. J. Am. Chem. Soc. 125, 1541-1550. doi: $10.1021 /$ ja028861q

Lehn, J.-M., Rigault, A., Siegel, J., Harrowfield, J. M., Chevrier, B., and Moras, D. (1987). Helicates. Proc. Natl. Acad. Sci. U.S.A. 84, 2565-2569. doi: 10.1073/pnas.84.9. 2565
Li, X., Zhan, C., Wang, Y., and Yao, J. (2008). Pyridine-imide oligomers. Chem. Commun. 2008, 2444-2446. doi: 10.1039/b800020d

Malinowski, E. R., and Howery, D. G. (1991). Factor Analysis in Chemistry. (New York, Chichester, Brisbane, Toronto: John Wiley).

Pangborn, A. B., Giardello, M. A., Grubbs, R. H., Rosen, R. K., and Timmers, F. J. (1996). Safe and convenient procedure for solvent purification. Organometallics 15, 1518-1520. doi: 10.1021/om9503712

Pauling, L., Corey, R. B., and Branson, H. R. (1951). The structure of proteins - 2 hydrogen-bonded helical configurations of the polypeptide chain. Proc. Natl. Acad. Sci. U.S.A. 37, 205-211. doi: 10.1073/pnas.37.4.205

Piguet, C., Bernardinelli, G., Bocquet, B., Quattropani, A., and Williams, A. F. (1992). Self-assembly of double and triple helices controlled through metal ion stereochemical preference. J. Am. Chem. Soc. 114, 7440-7451. doi: 10.1021/ja0004 $5 \mathrm{a} 016$

Piguet, C., and Bünzli, J.-C. G. (2010). "Self-assembled lanthanide helicates: from basic thermodynamics to applications," in Handbook on the Physics and Chemistry of Rare Earths, Chapter 247, Vol. 40, eds K. A. Gschneidner Jr., J.-C. G. Bünzli, and V. K. Pecharsky (Amsterdam: Elsevier Science, B.V), 301-553. doi: 10.1016/S0168-1273 (10)40007-0

Piguet, C., Bünzli, J.-C. G., Bernardinelli, G., Hopfgartner, G., and Williams, A. F. (1993). Self-assembly and photophysical properties of lanthanide dinuclear triple-helical complexes. J. Am. Chem. Soc. 115, 8197-8206. doi: 10.1021/ja00071a032

Piguet, C., Edder, C., Rigault, S., Bernardinelli, G., Bünzli, J.-C. G., and Hopfgartner, G. (2000). Isolated d-f pairs in supramolecular complexes with tunable structural and electronic properties. J. Chem. Soc. Dalton Trans. 2000, 3999-4006. doi: 10.1039/b003521l

Piguet, C., Hopfgartner, G., Williams, A. F., and Bünzli, J.-C. G. (1995a) Self-assembly of the first heterodinuclear d-f triple helix in solution. $J$. Chem. Soc. Chem. Commun. 1995, 491-493. doi: 10.1039/c399500 00491

Piguet, C., Rivara-Minten, E. Hopfgartner, G., and Bünzli, J.-C. G. (1995b). Molecular magnetism and iron(II) spin-state equilibrium as structural probes in heterodinuclear d-f complexes. Helv. Chim. Acta 78, 1651-1672. doi: 10.1002/hlca. 19950780704

Rodriguez-Cortinas, R., Avecilla, F., Platas-Iglesias, C., Imbert, D., Bünzli, J.-C. G., de Blas, A., et al. (2002). Structural and photophysical properties of heterobimetallic $4 \mathrm{f}-\mathrm{Zn}$ iminophenolate cryptates. Inorg. Chem. 41, 5336-5349. doi: $10.1021 / \mathrm{ic} 025587 \mathrm{~s}$

Schwarzenbach, G. (1957) Complexometric Titrations. (London: Chapman and Hall).

Song, B., Vandevyver, C. D. B., Chauvin, A.-S., and Bünzli, J.-C G. (2008). Time-resolved luminescence microscopy of bimetallic lanthanide helicates in living cells. Org. Biomol. Chem. 6, 4125-4133. doi: $10.1039 / \mathrm{b} 811427 \mathrm{~g}$
Torelli, S., Imbert, D., Cantuel, M., Bernardinelli, G., Delahaye, S., Hauser, A., et al. (2005). Tuning the decay time of lanthanidebased near infrared luminescence from micro- to milliseconds through d-f energy transfer in discrete heterobimetallic complexes. Chem. Eur. J. 11, 3228-3242. doi: 10.1002/chem. 200401158

Conflict of Interest Statement: The authors declare that the research was conducted in the absence of any commercial or financial relationships that could be construed as a potential conflict of interest.

Received: 20 May 2013; paper pending published: 20 July 2013; accepted: 13 August 2013; published online: 11 September 2013.

Citation: Deiters E, Eliseeva SV and Bünzli J-CG (2013) Self-assembly of a helical zinc-europium complex: speciation in aqueous solution and luminescence. Front. Chem. 1:15. doi: 10.3389/ fchem.2013.00015

This article was submitted to Inorganic Chemistry, a section of the journal Frontiers in Chemistry.

Copyright (c) 2013 Deiters, Eliseeva and Bünzli. This is an open-access article distributed under the terms of the Creative Commons Attribution License (CC BY). The use, distribution or reproduction in other forums is permitted, provided the original author(s) or licensor are credited and that the original publication in this journal is cited, in accordance with accepted academic practice. No use, distribution or reproduction is permitted which does not comply with these terms. 